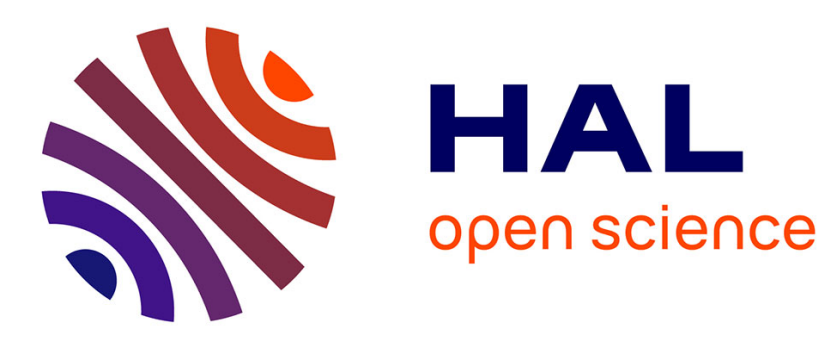

\title{
Hybrid local and teleseismic P-wave tomography in North Tanzania: role of inherited structures and magmatism on continental rifting
}

A Clutier, S Gautier, Christel Tiberi

\section{- To cite this version:}

A Clutier, S Gautier, Christel Tiberi. Hybrid local and teleseismic P-wave tomography in North Tanzania: role of inherited structures and magmatism on continental rifting. Geophysical Journal International, 2020, 10.1093/gji/ggaa538 . hal-03010588

\author{
HAL Id: hal-03010588 \\ https://hal.science/hal-03010588
}

Submitted on 17 Nov 2020

HAL is a multi-disciplinary open access archive for the deposit and dissemination of scientific research documents, whether they are published or not. The documents may come from teaching and research institutions in France or abroad, or from public or private research centers.
L'archive ouverte pluridisciplinaire HAL, est destinée au dépôt et à la diffusion de documents scientifiques de niveau recherche, publiés ou non, émanant des établissements d'enseignement et de recherche français ou étrangers, des laboratoires publics ou privés. 
GJI - Geodynamics and Tectonics

\title{
Hybrid local and teleseismic P-wave tomography in North Tanzania: role of inherited structures and magmatism on continental rifting
}

\author{
A. Clutier, S. Gautier, C. Tiberi \\ Géosciences Montpellier, Montpellier University, France \\ Email: adeline.clutier@umontpellier.fr
}

Abbreviated title: High Resolution tomography for the North Tanzanian Divergence

\section{Summary}

While local earthquake tomography is typically used to image the crust, this technique has restricted depth penetration due to short receiver-source distances. Regional tomography however aims to image the upper mantle from teleseismic events but suffers from poor resolution from 0 down to 40 $\mathrm{km}$ depth. We present here a hybrid method that combines the two approaches taking advantage of the short-wavelength resolution within the crust to better constrain the ray path at depth, and thus to improve the lithospheric imaging. Using this new method enhances the continuity or disruption of mantle anomalies towards the surface. Such hybrid tomographic images of crust-to-upper mantle structures are then critical to understand the relation and interplay between the thermal and mechanical lithospheric processes and the role in the localisation of the deformation at the surface. We apply our approach to the North Tanzanian Divergence (NTD), where those processes interact with a cold cratonic lithosphere. Our new tomographic images clearly demonstrate the impact of deep-seated processes on surface features. First, strong lateral velocity anomalies and clustered seismicity in the crust are consistent with the surface geology of the NTD (rifted basins, volcanoes and border faults). Then, at a lithospheric scale, the velocity distribution highlights the major role of inherited structures in guiding the rift opening. In particular, our study suggests a strong influence of the Masai cratonic block, south of the NTD, in the rift evolution. The transition from the NorthSouth axial valley into three diverging rift arms (Eyasi, Natron-Manyara and Pangani) is likely due 
to the change in rheology and to the presence of magma along inherited sutures between the craton and the mobile belts.

Key words: Seismic Tomography, Crustal imaging, Dynamics of lithosphere and mantle, Africa, Intra-plate processes

\section{Introduction}

Surface deformation in active continental rifts results from complex interactions between different geodynamic processes from the surface (e.g. surface erosion and sedimentation - Burov \& Poliakov, 2003), the lithosphere (e.g. crustal thinning or thickening, delamination, metasomatism - Thybo \& Nielsen, 2009; Van Wijk et al., 2010; Wallner \& Schmeling, 2011; Wang et al. 2015; Brune 2016) and the deep mantle (e.g. mantle flow, plume arrival - Huerta et al., 2009; Koptev et al., 2015; Currie \& Van Wijk, 2016; Njinju et al., 2019). A challenge in geodynamic research is to improve our understanding of those processes and how they interact, in particular the crust-mantle coupling which is a key parameter for the rift dynamics (e.g. Tíberi et al., 2000; Brune 2016; Koptev et al., 2016). Seismic tomography is now a well-known and classical tool to investigate crust-to-upper mantle velocity structure in order to first identify the lithospheric structures and the related processes, and second to determine their relationships.

Local and teleseismic body wave inversions are two approaches commonly used to obtain 3D velocity models for crustal and mantle scales, respectively. In the local approach, both earthquakes and seismic stations are located in the study area and absolute arrival-times of body waves are used to simultaneously determine hypocenter location and origin time, and 3D velocity structure (e.g. Aki \& Lee, 1976; Thurber, 1983; Zhao et al., 1992). The local tomography produces high-resolved images. Its resolution depends on the distribution of both the seismic network and the local seismicity. For rifting areas, the rare occurrence of earthquakes beneath the Moho discontinuities and the absence of $\mathrm{Pn} / \mathrm{Sn}$ refracted phases in some cases, prevent the local tomography from 
imaging deeper lithospheric structures (Maggi et al., 2000; Déverchère et al., 2001; Scholz 2002). In the teleseismic approach seismic stations are located in the study area, while earthquakes are located more than $30^{\circ}$ away from the network (e.g. Aki et al., 1977; Poupinet et al., 1997; Waldhauser et al., 2002). In order to get rid of the mutual long wavelength anomalies from lower mantle signal and to keep only the signal from the target volume, we work with relative arrival-time residuals (Zhao et al., 1994). This also permits to remove errors in event origin time and location (Aki et al., 1977; Evans \& Achauer 1993). Theoretically, relative arrival-time residuals of teleseismic events allow to investigate the crust and upper mantle structures. However, because of the relatively low-frequency content of teleseismic events and the near-vertical sampling pattern of the related incoming rays near the surface, this technique fails to precisely determine the crustal structure (Zhao et al., 1996; Waldhauser et al., 2002). At greater depths, teleseismic images can also be biased by crustal heterogeneity if an inadequate crustal model is used to correct for shallow structure (Humphreys \& Clayton, 1990; Waldhauser et al., 2002; Martin et al., 2005; Rawlinson \& Urvoy, 2006; Lei \& Zhao, 2007). Finally, due to those limitations, both methods used separately only poorly resolve the crust-upper mantle boundary. Yet, this major discontinuity in terms of composition as well as rheology is the location of complex processes, which control the coupling or decoupling between mantle dynamics and crustal deformation. In active rifting areas, this includes magmatic underplating (e.g. Thybo \& Artemieva, 2013), mantle delamination and metasomatism (e.g. Wallner \& Schmeling, 2011; Wang et al. 2015), crustal thinning or thickening (e.g. Gao et al. 2003; Siler \& Karson, 2009; Wang \& Currie, 2015). Detailed seismic images allow to shed light on the contributions of controlling factors such as temperature, fluid, composition which modifies the rheological state of the lithosphere and are related to the surface deformation (e.g. Albaric et al., 2009; Burov 2011; Brune 2016; Koptev et al., 2016; Sippel et al., 2017). Consequently, the development of new models with much higher resolution around this transition is required to inyestigate the contribution of those factors in a rifting process. 
In order to obtain better-resolved tomographic images at both crustal and uppermost mantle depths, local and teleseismic data can be combined in joint inversion schemes (e.g. Roecker et al., 1993; Zhao et al., 1994; Zhang et al., 2009; Nyamwandha et al., 2016). A 1D starting model from surface to upper/lower mantle boundary is used in most cases (Zhao et al., 1994; Lei et al., 2009; Nyamwandha et al., 2016), while Waldhauser et al. (2002) and Sandoval et al. (2003) integrate an a priori $3 \mathrm{D}$ crustal model in their starting model. Including local events usually allows to better constrain the shallow velocity structure and to separate the travel-time contribution between the crust and the mantle. In particular, Huang et al. (2014) point out that the joint inversion provides less vertical smearing than inversions based solely on teleseismic data and also contribute to better constrain the velocity structures. However, combining local and teleseismic data in the same inversion procedure raises the question of a common parameterization. For example, the choice of the grid system is important to accommodate different ray sampling and related varied spatial resolution between crust and mantle (Kuo-Chen et al., 2012; Huang et al., 2014). The joint approach also requires weighting parameters in order to ponder the respective sensitivity of the inversion to teleseismic and local data (Huang et al., 2015, Eberhart-Philipps \& Fry, 2018). The aim of this operation is to consider the impact of different amounts of observations and different sourcestation configurations between teleseismic and local investigations. In practice, a high degree of uncertainty in parametrization appears as a major challenge of the local-teleseismic joint inversion.

Here, our aim is to develop a different approach to obtain the most adapted resolution with depth in the tomographic images. For this purpose, we constrain the crustal structure from a local tomographic inversion, that we further include into a teleseismic lithospheric inversion. We apply this tomographic scheme on a real case that includes both tectonic and magmatic processes, and for which recent but distinct local and teleseismic studies have already been conducted: the North Tanzania Divergence, hereafter referred to NTD (Fig. 1) (Roecker et al., 2017; Weinstein et al., 2017; Tiberi et al., 2019). The NTD is located at the southern tip of the Eastern Branch of the East African Rift, and its surface expression results from interactions between deep-mantle (mantle 
plume), lithospheric (inherited rheology and stratification, melting,...) and crustal (dykes, sills, faults,...) processes (Weeraratne et al., 2003; Baer et al., 2008; Le Gall et al., 2008; Huerta et al., 2009; Albaric et al., 2010; Mulibo \& Nyblade, 2013; Biggs et al., 2013; Muirhead et al., 2016; Koptev et al., 2016; Ebinger et al., 2017; Adams et al., 2018; Tepp et al., 2018; Oliva et al., 2019). Recent geophysical (Calais et al., 2008; O’Donnell et al., 2013; Albaric et al., 2014; Selway et al., 2014; Roecker et al., 2017; Weinstein et al., 2017; Tiberi et al., 2019; Plasman et al., 2017 \& 2019) and geochemical studies (Hui et al., 2015; Lee et al., 2016; Muirhead et al., 2016; Baudouin et al., 2016) have demonstrated the role of fluids, thermal and compositional modifications at different scales in this region. However, due to the different target structures imaged by each method and their inherent resolution, the relative role of hydration, inherited rheology, suture zones, thermal state and their interplay in the resulting surface deformation are difficult to assess. Our new method is here particularly suitable to investigate the lateral and vertical control of the lithospheric deformation, and how deep-seated processes impact surface features.

In this paper, we begin with a background section in which we summarize both the tectonic and geodynamic framework of the NTD. We then present the data, our hybrid tomographic approach, some synthetic tests to assess the resolution of the fomographic images and the tomographic results.

We first discuss the improvement of the crust-to-upper-mantle tomographic images. We then interpret our results in terms of geodynamical implications. In the crust, the velocity contrasts and seismicity distribution highlight lithological units, faults, melt zones (storage or intrusion) and their extension in depth. We then investigate the role of the mantle structural heterogeneities, magma and rheology changes in the rift opening and their contributions to the surface deformation. In particular, we question the role of large-scale inherited structures on the location, nature and storage of magmatic processes in the NTD. At the end, our images allow us to propose a scenario for the rift evolution. 


\section{Geological setting}

The North Tanzanian Divergence (NTD) is situated at the southern tip of the Eastern branch of the East African Rift (EAR). This zone is the location of the rift initiation and is subdivided in 3 other branches: Eyasi, Magadi-Natron-Manyara and Pangani (Fig. 1). The NTD is propagating from North to South in a thick and strong lithosphere (Petit \& Ebinger, 2000; Perez-Gussinye et al., 2009; Albaric et al., 2009) along the Proterozoic Eastern orogenic belts (Sippel et al., 2017) and into the Archean Tanzanian Craton, whose limits are still debated (Ebinger et al., 1997; Le Gall et al., 2008; Albaric et al., 2014). Magadi-Natron-Manyara (MNM) rift zone lies between the Eyasi rift in the Archaean craton to the west and the Pangani rift in the Neoproterozoic Mozambique-belt lithosphere (Fritz et al. 2013) to the East (Fig. 1). The aseismic Masai block (Albaric et al., 2010) is located East to the Mbulu domain and its Northern border roughly coincides with the West-East

transverse Ngorongoro-Kilimanjaro volcanic chain, i.e. perpendicular to the main rift axis. Even if the Masai block has long been assimilated to a rigid lithospheric block(Foster et al., 1997; Le Gall et al., 2008; Isola et al., 2014), its geological origin (orogenic belt or craton fragment) still remains ambiguous (e.g. Ebinger et al., 1997; Le Gall et al.,2008; Fritz et al., 2013, Tiberi et al., 2019). Both the surface boundaries and the geometry at depth of the Archean craton, the Proterozoic orogenic belts and the Masai block are still badly known while their role in driving mantle plume up to the surface is strongly suspected (Koptey et al. 2016).

The NTD is characterized by seismically active faults and eruptive centres. In this area, the seismicity is clustered (Fig. 1, upper right map). The seismicity is mainly restricted to the first 20 km depth in the Northern part near the Natron Lake (Weinstein et al., 2017), and part of it is attributed to seismo-volcanic crisis (Calais et al., 2008) as well as fluid migration (Lee et al., 2016; Weinstein et al., 2017; Oliva et al., 2019). On the contrary, the Manyara and Eyasi basins at the craton boundary are characterized by deep earthquakes $(\sim 30 \mathrm{~km}$ depth), whose origin remains debated (Nyblade \& Robinson, 1994; Albaric et al. 2014). 


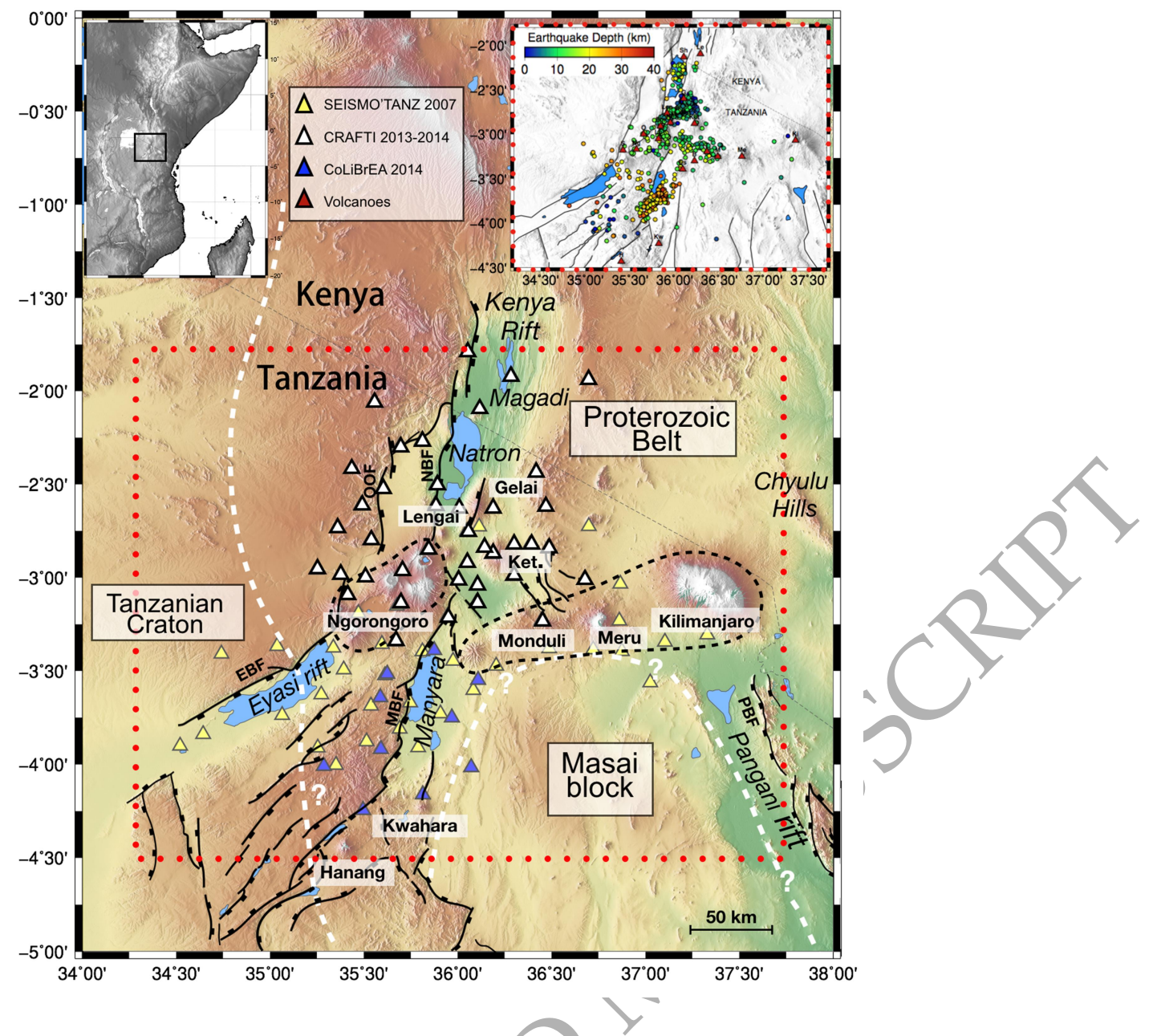

Figure 1: Map of the study area indicating the main geological features and the used seismic networks (modified from Tiberi et al., 2019). Seismic stations aye represented by yellow, white and blue triangles. Presumed limits of the Tanzanian Craton and the Masai block are outlined by dashed white lines. Main volcanic edifices are written in bold and encircled by the dashed black lines (schematized by red triangles in the upper right inset. Major normal faults are represented by continuous ticked black lines: OOF - Ol Doinyo OgQl, Fault; NBF - Natron Border Fault; EBF - Eyasi Border Fault; MBF - Manyara Border Fault, PBF - Pangani Border Fault. Red dotted square delimits the spatial extension of the local velocity model inserted in the teleseismic inversion. Volcanoes from inset: B Burko, Em-Embagdi, Es-Essimingor, G-Gelai, H-Hanang, Ke - Kerimasi, Ket-Ketumbeine, KiKilimanjaro, Ky - Kwahara, Le - Lenderut, Len - Ol Doinyo Lengai, Lo - Loolmasin, Me - Meru, MMónduli, Ng, Ngorongoro, O-Olmoti, S-Sadiman, Sh-Shombole, T-Tarosero. 
From North to South, volcanism is spatially sparser. Eruptive centres are distributed along two principal magmatic axes: the main North-South rift axis and an East-West axis, which extends from the Ngorongoro in the West to the Kilimanjaro in the East (e.g. Nonnotte, 2007; Mana et al. 2015; Baudouin et al. 2016). The reliable ages available in the NTD volcanism indicate changes in the locus of the volcanism over time, with earliest volcanism occurring in the South-West section of the NTD and then a propagation towards both the North and the East. Ol Doinyo Lengai (Fig. 1) is currently the only active volcano in this area. The magmatic activity in the NTD region is characterized by episodic discrete events or large pulses. Two major pluses in magmatic activity are identified, at c. $2.3 \mathrm{Ma}$ and c. 1.2 Ma (Mana et al., 2015). Mana et al. (2015) suggest that these two pulses are linked to a main rifting event. In addition, many authors (Foster et al., 1997; Le Gall et al., 2008; Weinstein et al., 2017) mention a possible interdependence of faulting and volcanic activity in the spatial and temporal development of the NTD. The Ngorongoro volcano had an almost continuous activity between 3.7-1.83 Ma (Nonnotte, 2007). This event was then followed by faulting episodes along the Ol Doinyo Ogol Fault (OOF) and the Eyasi Border Fault (EBF) (Gama, 2018). The two major magmatic pulses and the Meru principal volcanic phase (2.0-1.5 Ma, Wilkinson et al., 1986) preceded faulting episodes along the Pangani Border Fault (PBF), Natron Border Fault (NBF) and Manyara Border Fault (MBE) activation or reactivation (Gama 2018).

The NTD system is thus a complex geodynamic zone, involving magmatism and tectonic processes which interact at different depths. In the crust, the evolution of the rift and its morphology is strongly linked to inherited structures, particularly the Proterozoic belts and the craton boundaries (Albaric et al., 2014; Weinstein et al., 2017; Roecker et al., 2017; Plasman et al., 2017 \& 2019; Tiberi et al., 2019). In the mantle, Archean and Proterozoic units interact with the mantle upwelling implying thermal and compositional modifications in the mantle lithosphere (Ritsema et al., 1998; Huerta et al., 2009; Mulibo \& Nyblade, 2013; Koptev et al., 2018; Tiberi et al., 2019, Muirhead et al., 2020). Because of different resolutions and depth of investigation, the crust and the mantle are mostly investigated separately. This masks the potential interconnections between mantle and 
crustal structures and prevents from being conclusive on the influence of thermal and mechanical mantle processes on the location of the deformation at the surface. In this study, we propose a new tomography strategy to investigate the NTD from the surface down to $200 \mathrm{~km}$ depth in order to better constrain crustal-to-upper-mantle features.

\section{Hybrid tomographic approach and application to the}

\section{NTD}

In order to avoid the complexity of a full joint inversion and to enhance the depth/resolution of teleseismic tomography, we propose here a hybrid approach, which consists in teleseismic inversion with a strong crustal constraint. Our approach can be split into 3 major steps. We first conduct a local tomography study to constrain as precisely as possible the crustal part through the numerous local seismic events $(<30 \mathrm{~km}$ depth). The resulting 3D local model is then inserted within the initial layered 1D regional model. Finally, we proceed to a teleseismic tomographic inversion for lithospheric structures $(<200 \mathrm{~km}$ depth) by using this new set-up initial model. Following this approach, we investigate the contributions of both a finer grid in the first $40 \mathrm{~km}$ and a 3D crustal velocity structure in imaging the upper mantle structure.

\subsection{Local Tomography}

\section{Local earthquake data}

The seismic network is composed of 78 stations of the CRAFTI (2013-2014, 35 broad-band sensors, 1 year) (https://doi.org/10.7914/SN/XJ 2013), the CoLiBrEA (2014, 9 short-period sensors, 8 months) experiments with a sample rate of $50 \mathrm{~Hz}$ everywhere, and the SEISMO'TANZ experiment (2007, 34 enlarged band or broad-band sensors with a sample rate of $125 \mathrm{~Hz}, 6$ months)

(Fig. 1). We take advantage of this dense network to supply the largest compilation of body-wave 
data for the considered area. Because the local tomographic routine (Gautier et al., 2006) only used the direct crustal phases, Moho-refracted phases are not considered here, even if they were collected by data analyses. P- and S-wave first arrival-times were hand-picked on Butterworth-filtered (1-2 $\mathrm{Hz}$ ) vertical and transverse components, respectively. A quality factor was also manually assigned to the different readings to account for uncertainties in arrival-time determination. See Weinstein et al. (2017), Roecker et al. (2017), Albaric et al. (2010) for more details about stations, network configuration and data processing. The initial database encompasses 4080 events relocated in the 1D velocity model proposed by Albaric et al. (2010). It results in 51052 P-wave and 52288 Swave arrival-times.

In order to obtain the most reliable and uniform dataset, we performed a selection using different criteria (events located within the tomographic model boundaries, pick qualities given by the operator greater than 3 for $\mathrm{P}$ and 4 for S-waves, a minimum number of $8 \mathrm{P}$ and $4 \mathrm{~S}$ records per event, an azimuthal gap less than $180^{\circ}$ ) and we restricted our selection to 3432 local earthquakes with $\mathrm{M} \geq 1.0,44671 \mathrm{P}$ - and $40597 \mathrm{~S}$-first arrival-times.

\section{Initial model and grid parameterisation}

The local tomographic inversion is applied over a $390 \times 300 \mathrm{~km}^{2}$ area and is defined up to $60 \mathrm{~km}$ depth in order to include both all the stations and all the ray paths (Fig. 1 and supplementary material S2 for ray paths). Following synthetic tests and using the real event-station geometry, we fix both the grid spacing and the parametrization of the inversion to optimize the resolution. The velocity model is composed of $27 \times 21 \times 14$ nodes in West-East, South-North and vertical directions, respectively. The node spacing we used is $15 \mathrm{~km}$ in horizontal and $5 \mathrm{~km}$ in vertical directions.

The 1D P-velocity starting model is from Albaric et al. (2010) and updated from Roecker et al. (2017) in order to ensure a rapid convergence for the inversion (Kissling et al., 1994). In order to 
deduce the initial S-velocity starting model, we used a Vp/Vs ratio of 1.72 in accordance with the final model proposed by Roecker et al. (2017).

\section{Inversion process}

We used a delayed-time tomography (Gautier et al., 2006; Priolo et al., 2012) which simultaneously inverts for both the P- and S- velocity distributions and the hypocenter parameters (location and origin time). Even if only the P-velocity model was used for the teleseismic inversion, we coupled all these parameters in the local inversion in order to obtain the more reliable hypocenter-velocity model (Thurber, 1992; Ryberg \& Haberland, 2019). This method provides smooth P- and Svelocity models estimated on a 3D, regularly spaced grid.

This approach is based on an iterative linearized tomographic scheme. First-arrival times are computed by solving the Eikonal equation with a finite-difference algorithm (Podvin \& Lecomte, 1991). Then a posteriori ray-tracing method based on time gradient is used to re-evaluate traveltimes and to estimate partial derivatives along each ray path, both for slowness and hypocenter parameters. Normalization or scaling of the resulting derivative matrix is performed for a better reconstruction of the different parameters. This operation removes influences of the different parameters and considers the sensitivity of the data to each class of parameters. A least-square process using the LSQR method (Paige \& Saunders, 1982) is used for the inversion. The inversion process is iterative and updates both the $3 \mathrm{D}$ velocity distributions and the earthquake hypocenter parameters at each iteration.

In order to fix suitable damping values and scaling factors, we checked the good convergence and result of the inversion through the final RMS decrease for extensive regularisation tests (see supplementary material $\mathrm{S} 1$ ). We first set the damping values to 0.7 and 0.35 for $\mathrm{P}$ and $\mathrm{S}$ waves, respectively. The scaling factors were then set to 1 for $\mathrm{P}$ wave, 2 for $\mathrm{S}$ wave and 5 for both the location and the origin time of earthquakes. 


\section{Resolution tests}

Because the spatial resolution of the estimated model is highly dependent on the ray coverage within the target area, we test the resolving power of our dataset by using synthetic checkerboard tests with the real events and stations distribution. The reference model is created by adding alternating positive and negative velocity perturbations to the final tomographic model in a checkerboard fashion (Fig. 2), protocol proposed in Gautier et al. (2006). This velocity perturbation should be strong compared to the numerical noise level and yet small enough to avoid noticeable disturbances in the ray coverage. In order to simulate errors in arrival times such as picking errors, travel-times are then computed in the reference model and a noise term is added to this synthetic data set from a uniform distribution between -0.05 and $0.05 \mathrm{~s}$. The resulting synthetic data are then inverted using the same procedure and parametrization that were used for the real data. The final tomographic model is used as the input in this inversion process. The recovered velocity pattern is then compared to this input model in order to assess the resolution by looking at the smearing of the velocity patterns. In particular, we estimate the model resolution for some parameters like the amplitude, the location, the size and the shape of the reconstructed anomalies.

We performed several checkerboard tests for input anomalies $\left(700 \mathrm{~m} . \mathrm{s}^{-1}\right.$ for $\mathrm{Vp}$ and $400 \mathrm{~m} . \mathrm{s}^{-1}$ for Vs) of different sizes and locations. The resolution is better above $20 \mathrm{~km}$ depth and the smallest well-reconstructed pattern anomaly in the crust corresponds to $30 \times 30 \times 20 \mathrm{~km}^{3}$ that defines the minimum anomaly size we are able to resolve in local tomographic inversions. Fig. 2 shows the input model and resolved models in map views and cross-sections, respectively.

In the central part of the target area with enough ray crossing (See supplementary material S2 for ray coverage), both the shape and the amplitude of the input anomalies are correctly estimated for both P-and S- velocity models down to $40 \mathrm{~km}$ depth. The recovery amplitude is reduced below 30 $\mathrm{km}$ depth but the geometry of the recovered pattern is still good. Not surprisingly the resolving power gradually decreases towards the lateral edges of the model, in particular in the Southeastern 
and Northeastern parts of the model (south of $3.7^{\circ} \mathrm{S}$ and north of $2.6^{\circ} \mathrm{S}$, respectively). Lateral NESW smearing effects exist in the resolved checkers below $25 \mathrm{~km}$ depth and this effect is more pronounced in the East. This is mainly due to uneven distribution of both earthquakes and stations in this area, resulting in an uneven ray coverage within the crust. From the synthetic tests, we conclude that the $3 \mathrm{D}$ velocity models are well-constrained between $35^{\circ}$ and $36.8^{\circ} \mathrm{E}$, except in the Southeastern region where a lack of resolution is observed beyond $36^{\circ} \mathrm{E}$.
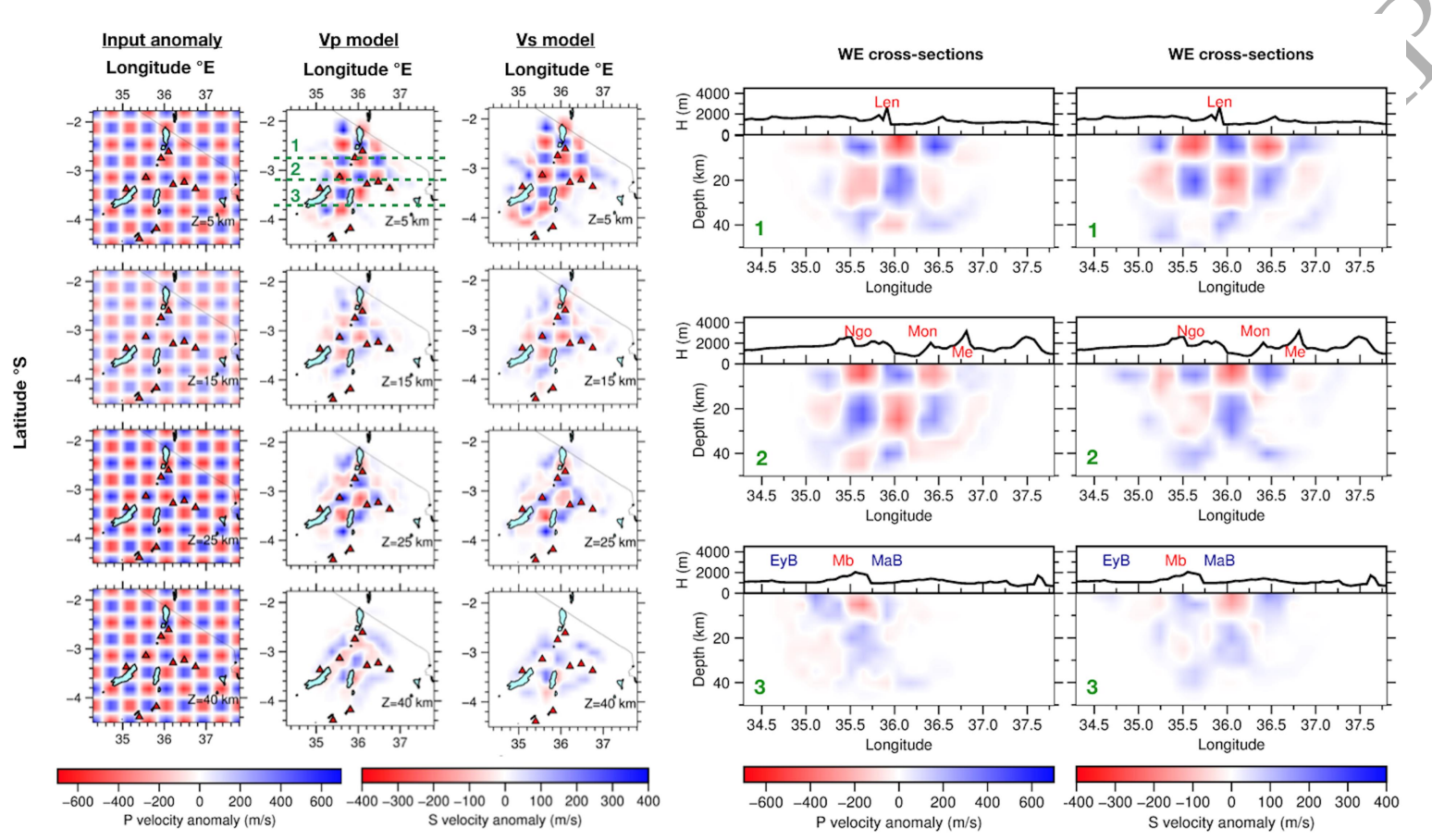

Figure 2: Representative results of the checkerboard tests for the P-and S-velocity models. The lefthand panel indicates the true Kheckerboard anomaly added to the $3 D$ final velocity model $\left(700 \mathrm{~m}^{-1} \mathrm{~s}^{-1}\right.$ for Vp and $400 \mathrm{~m} . \mathrm{s}^{-1}$ for $\mathrm{VS}$ ) and the retrieved patterns after tomographic inversion in map views. The checkers are shown along three WE cross-sections on the right-hand side, for both $P$ and $S$ velocity anomalies. Location of these sections are shown by dashed green lines in the first image of the VP model on the left side. Geographical references mentioned in cross-sections are from $W$ to $E$ : EyB = Eyari Basin, $M b=$ Mbulu domain, Ngo = Ngorongoro crater, MaB = Manyara Basin, and Len = Lengai, Mon= Monduli, Me $=$ Meru volcanoes. 


\section{Application to the NTD}

No significant residual variance reduction was achieved after 15 iterations for the crustal delay-time inversion. The average of residuals decreases from $0.36 \mathrm{~s}$ to $0.185 \mathrm{~s}(51 \%)$, and more specifically from $0.34 \mathrm{~s}$ to $0.17 \mathrm{~s}$ for P-travel-times and from $0.4 \mathrm{~s}$ and $0.2 \mathrm{~s}$ for the S-travel-times.

Combining three temporary seismological networks allows us to first enclose a broader area in the NTD zone than previous crustal studies (Albaric et al., 2014; Roecker et al., 2017). Second, both the $3 \mathrm{D}$ velocity models and the earthquakes distribution from our local tomography (Figs. 3, 4 and 5) largely agrees with previous tomographic surveys in the region (e.g. Albaric et al., 2014; Roecker et al., 2017; Weinstein et al., 2017). Our Vp and Vs images point out that the crust is relatively complex with strong lateral velocity variations in the upper and mid crust. $\mathrm{.}$ 

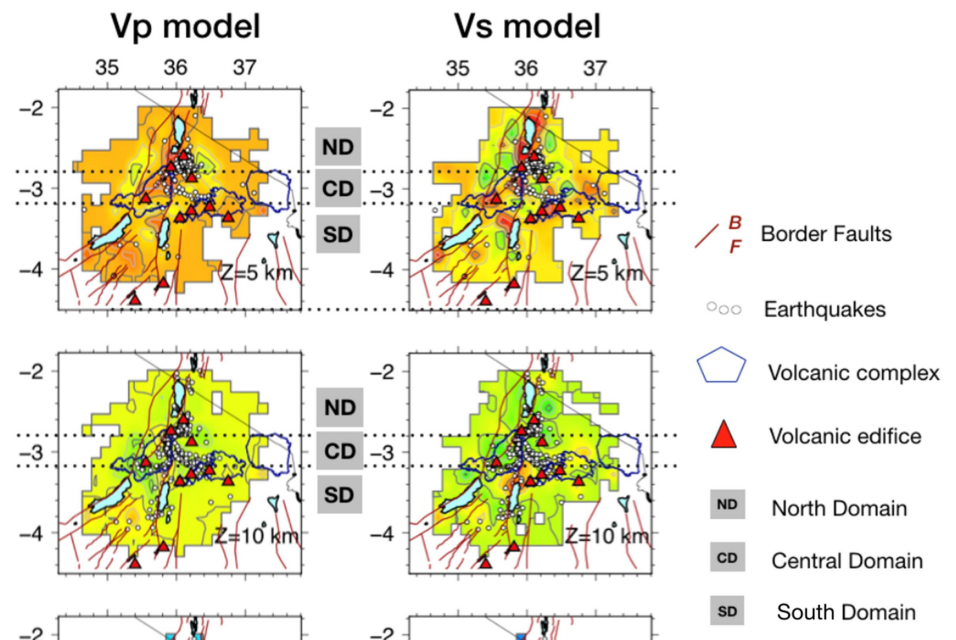

Figure 3: Vp and Vs velocity models
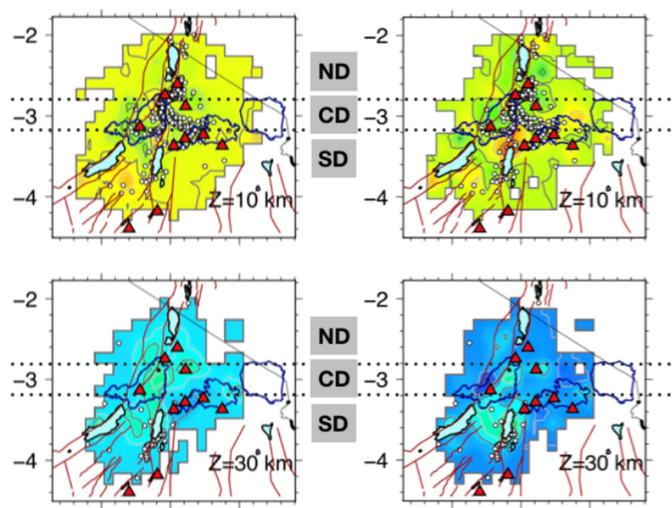

SD

from the local tomographic inversion for 4 different depths. Velocity isolines are indicated in continuous grey lines every $100 \mathrm{~m} \cdot \mathrm{s}^{-1}$ Triangles represent the volcanic edifices and the dark blue contours mark the volcanic complexes. Dark red lines
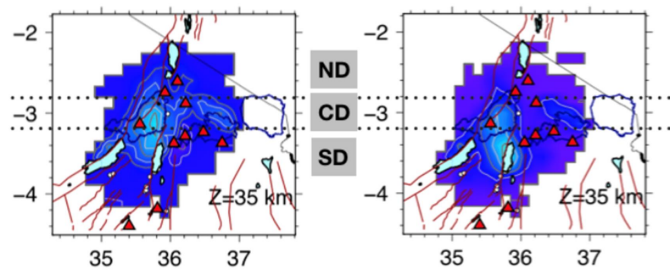
underline the matn fault in the NTD.

$\begin{array}{cccccccccccccc}6.0 & 6.5 & 7.0 & 7.5 & 8.0 & 3.2 & 3.4 & 3.6 & 3.8 & 4.0 & 4.2 & 4.4 & 4.6 & 4.8 \\ & \text { P velocity } & (\mathrm{km} / \mathrm{s})\end{array}$ derline the math allis in the NTD. 

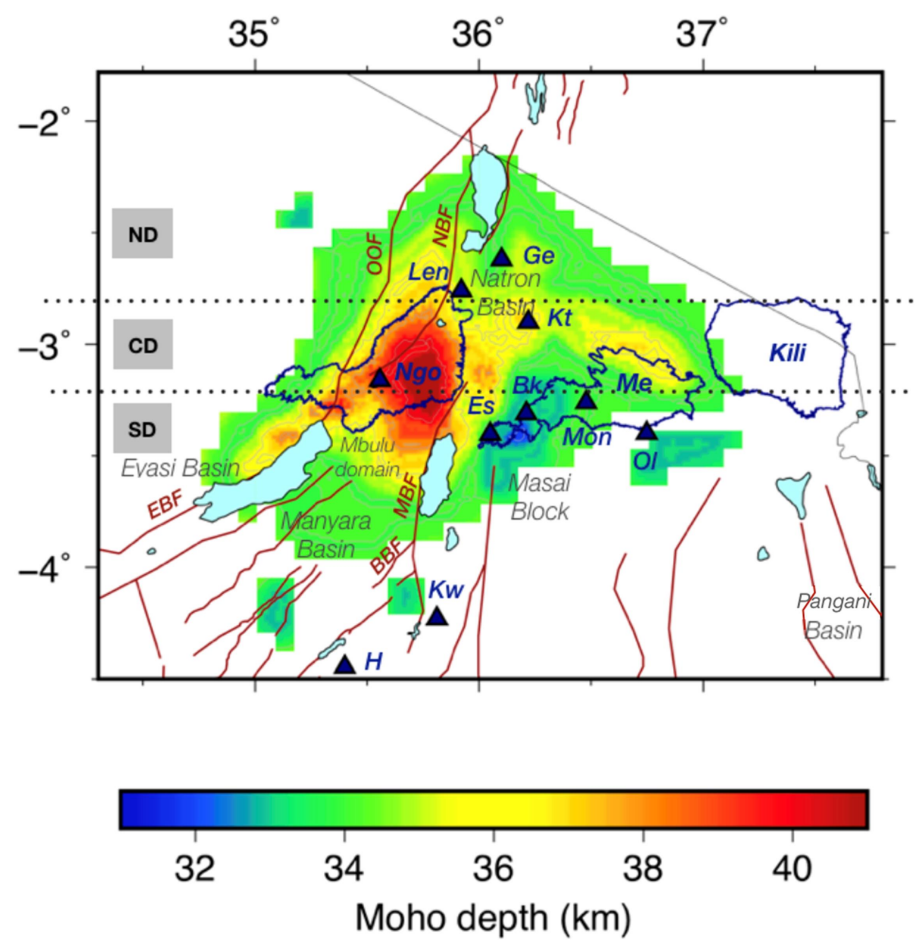

$\angle B F$ Border Faults $\square \triangle K_{w} \quad$ Volcanic complex and edifice

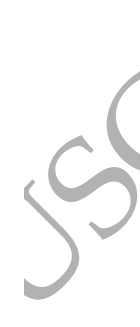

ND CD SD North, Central, South Domain

Figure 4: The Moho depth map of the studied area deduced from the Prvelocity model for Vp equals to $7.7 \mathrm{~km} . \mathrm{s}^{-1}$ (Birt et al., 1997). Triangles represent the volcanic edifices and the dark blue contours mark the volcanic complexes. Dark red lines underline the main faults in the NTD. Some additional geodynamic information used in the text for Anterpretation are also reported, as the name of some basins, border faults and volcanic edifices. Ol=Olmani Me=Meru, Mon=Monduli, Bk=Burko, Es=Essemingor, Kt=Ketumbeine, Ge=Geldi, Len=Ol Doinyo Lengai, H=Hanang, Kw=Kawahara, Ngo $=$ Ngorongoro volcanoes, $Q \mathcal{Q O F}=O \mathrm{Ol}$ Doinyo Ogol Fault, NBF=Natron Border Fault, EBF=Eyasi Border Fault, $M B F=$ Manyara Border Fault, BBF - Balangida Border Fault.

In the shallower crust, the $\mathrm{P}$ and $\mathrm{S}$ wave velocity solutions are quite similar regarding the spatial distribution of the anomalies but more contrasted magnitudes are observed in the S-wave model (Fig. 3). North of latitude $2.8^{\circ} \mathrm{S}$ (Fig. 3 and Fig. 5, see ND label), we observe low velocities down to $10-15 \mathrm{~km}$ depth below the Natron basin $\left(\mathrm{Vs} \sim 3.3 \mathrm{~km} \cdot \mathrm{s}^{-1}\right)$, which contrast with high velocities below the rift flanks $\left(\mathrm{Vs} \sim 3.9 \mathrm{~km} \cdot \mathrm{s}^{-1}\right)$. Our results are similar to those found by Roecker et al. 
(2017) who related this velocity reduction within the rift valley to a thick sequence of sediments in the upper $5 \mathrm{~km}$ (Birt et al., 1997; Ebinger et al., 1997) and active volcanism in the mid-crust laterally delimited by deeply rooted rift border faults in the western side (Le Gall et al., 2008; Weinstein et al., 2017). Low Vs anomalies, probably related to deep sedimentary or volcanic sequences (Mana et al., 2015; Plasman et al., 2019), are also detected in the mid-crust below the EW transverse volcanic belt, except below the Ngorongoro volcanic complex where a high-velocity pattern is detected at $10 \mathrm{~km}$ depth (Figs. 3 and 5, see CD label). Finally, our crustal tomographic images verify the presence of a low velocity zone down to $15 \mathrm{~km}$ depth beneath the northern part of the Mbulu domain, as previously suggested by Albaric et al. (2014) with less resolution than our study (Fig. 3 and Fig. 5, see SD).

The seismicity is mainly clustered and is localized along basin border faults of Natron and Manyara or below volcanic edifices (Le Gall et al., 2008) and zones of inferred dykes and sills intrusions (Oliva et al. 2019) (Fig. 1, upper right map). Between $2.4^{\circ} \mathrm{S}$ and $3{ }^{\circ} \mathrm{S}$, South of the Natron Lake, we mainly observe upper crustal earthquakes $(\mathrm{z}>17 \mathrm{~km})$ aligned along $\mathrm{a} \sim \mathrm{N} 45^{\circ} \mathrm{E}$ direction within the rift valley (Figs. 1 and 3). This earthquake swarm is located in the central low velocity zone and is parallel to the 2007 dyke intrusion within the upper crust)(Calais et al., 2008; Biggs et al., 2013). Its direction also corresponds to the Gelai-Olmoti volcanic axis, and evidences possible strain accommodation by fault-magma interactions in continental rifting (e.g. Muirhead et al., 2015; Weinstein et al., 2017). South of $2.8^{\circ} \mathrm{S}$, a significant part of the seismic events moves along a $\sim \mathrm{N} 120^{\circ} \mathrm{E}$ trend towards the Meru volcanic edifice. Because this cluster matches the Engaruka fault trace and continues eastward at the base of the low Vs zone at 10-15 km depth under the transverse volcanic chain (Fig. 5), our results support the presence of a transfer fault zone between the NatronManyara and the Pangani rift sectors, as proposed by Le Gall et al. (2008) and Weinstein et al. (2017). South of the Manyara lake (Figs. 1 and 3), earthquakes are distributed along an elongated cluster in the lower crust $(\mathrm{z}>20 \mathrm{~km})$ with roughly the same $\mathrm{N} 45^{\circ} \mathrm{E}$ orientation as the northern Natron swarm (Albaric et al., 2014). This swarm coincides with a sharp S-wave velocity gradient at 
the contact between the Mbulu domain and the Masai Cratonic block (Fig. 5, SN section). Plasman et al. (2019) combined resistivity cross-sections with $\mathrm{Vp} / \mathrm{Vs}$ images obtained in the region to discuss the presence of gas or melt at depth. In particular, they showed that the seismicity localized at $30 \mathrm{~km}$ depth delimits the top of both a high conductive and high $\mathrm{Vp} / \mathrm{Vs}$ ratio zone. Several processes have been proposed to explain this lower crustal swarm such as magma upwelling (Plasman et al., 2019), a shear zone at the boundary between two major tectonic units (Plasman et $a l ., 2019$ ) and deep fluid pressure arising from melts (Albaric et al., 2014). Finally, little to no seismicity is recorded North-East and South-East of the studied region.

Vertical cross-sections (Fig. 5) point out that velocity variations at around $40 \mathrm{~km}$ depth correlate with the crustal thickness deduced from previous receiver function analyses (Plasman et al,, 2017). We took advantage of the local 3D velocity model to extract a continuous Moho topography map of the studied area (Fig. 4), choosing an isovelocity surface of $7.7 \mathrm{~km} . \mathrm{s}^{-1}$ as a representative Moho proxy in this area (Birt et al., 1997). The most notable result of our local inversion is a thickening of the crust, from North to South within the rift area and beneath the EW volcanic chain (Figs. 3, 4 and 5). A maximum depth of about $42 \mathrm{~km}$ is reached in the central domain, under the Ngorongoro volcanic complex and the northern part of the Mbulu domain in accordance with the results reported by Plasman et al. (2017). Our study associates this thicker crust with low velocities from $30 \mathrm{~km}$ down to $40 \mathrm{~km}$ depth. This low-velocity lower crust extends from the Eyasi border fault (EBF) and the western boundary of the crater Highlands to the Manyara border fault (MBF) which underline the limit between the Manyara basin and the Masai block (Fig. 3 and 5). Sparse low velocity zones are also imaged eastward North of the EW volcanic chain (Fig. 3). Across the Natron basin, the Pwave distribution points out a slight narrow crustal thinning of the crust within the rift valley (Fig. 3, see label ND). Variations of Moho geometry and lower crust structures in this area have been imaged in previous geophysical studies (e.g. Tesha et al., 1997; Plasman et al., 2017 \& 2019; Tiberi et al., 2019) and will be discussed in the following sections. 

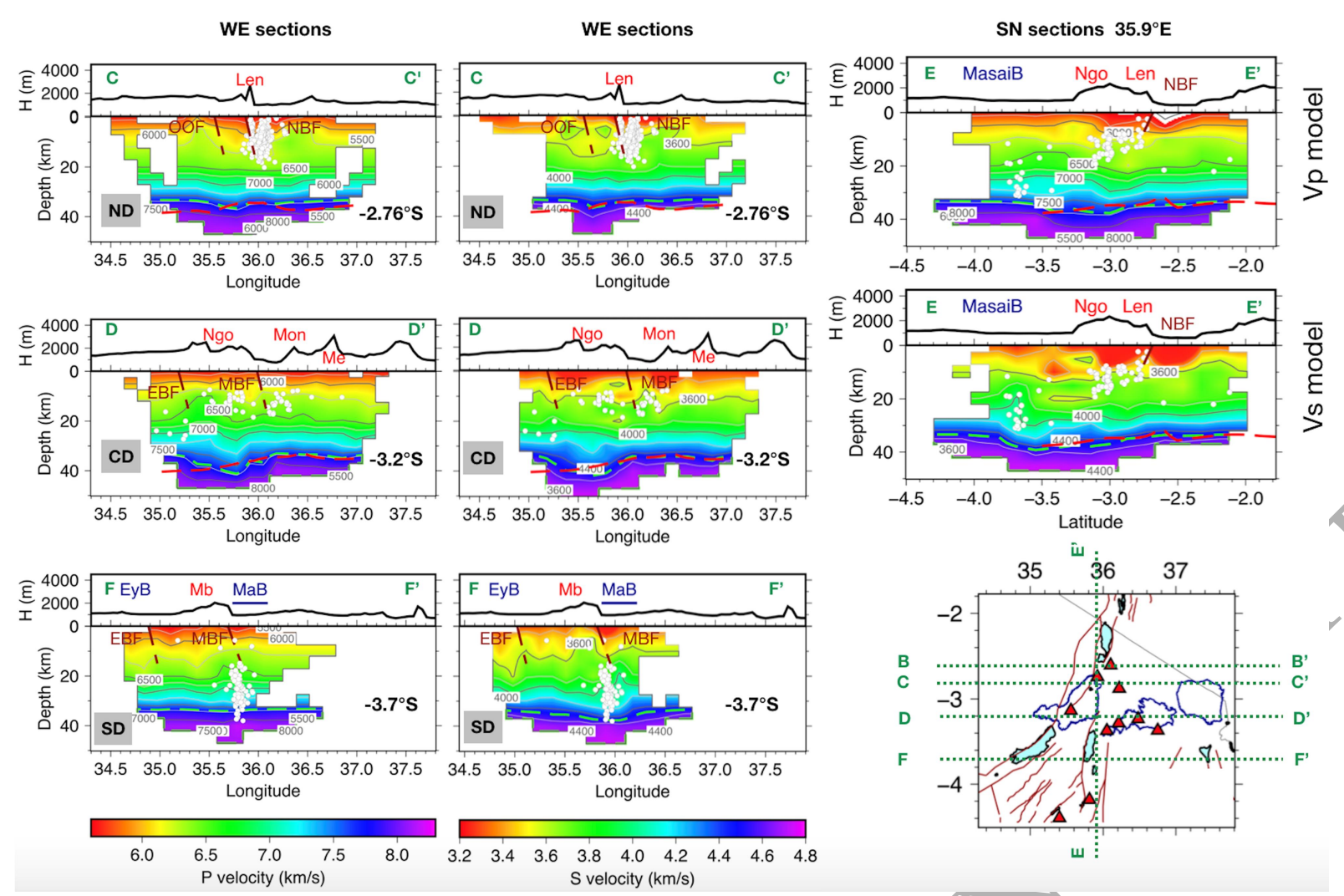

Figure 5: Vp and Vs models resulting from the local tomographic infersion for EW and SN vertical cross-sections. Earthquakes are represented with white dots and borderfaults with dark red lines. The dashed red lines indicate the Moho deduced from Plasmaper al. (2017) and the green ones the Moho estimated in this study (Fig. 4). Some additional geodynamic information used in the text for interpretation are also reported, as the name of some basins, border faults and volcanic edifices. $M e=M e r u$, Mon=Monduli, Len=Ol Doingo Lengai, Ngo=Ngorongoro volcanoes, OOF=Ol Doinyo Ogol Fault, MBF=Manyara Borden Fault, NBF=Natron Border Fault, Mb=Mbulu domain, MasaiB= Masai cratonic unit, MaB=Manyara Basin, EyB=Eyasi Basin.

\subsection{Teleseismic tomography}

\section{Teleseismic earthquake data}

For the teleseismic inversion, we used the dataset compiled by Tiberi et al. (2019) and derived from the 2013-2015 CRAFTI and CoLiBrEA experiments. This dataset is obtained from P- and PP-wave arrivals for 160 earthquakes of $\mathrm{Mb}>6.0$ that were recorded by the 45 temporary seismic broad- 
band stations deployed in the Magadi, Natron and Manyara rift segments in 2013-2014 and 2015

(Fig. 1). The waveforms were filtered with a two-pass Butterworth filter with corner frequencies of 0.08 and $0.8 \mathrm{~Hz}$. Travel-time residuals relative to IASP91 theoretical arrival-times (Kennett \& Engdahl, 1991) are computed thanks to a cross-correlation technique (VanDecar \& Crosson, 1995). In total, 4047 relative arrival-time residuals with a reasonably homogeneous azimuthal distribution are used in the teleseismic inversion. The mean relative residuals range from -1.6 to $1.1 \mathrm{~s}$ suggesting a very heterogeneous lithospheric structure.

\section{Initial model and grid parameterization}

The main value of our approach is the use of a complex velocity model as an input in the teleseismic tomography procedure (Waldhauser et al., 2002; Martin et al.,2005, Rawlinson et al., 2014). The initial background P-wave velocity model is composed of the IASP91 model (Kennett \& Engdahl, 1991). We include in this 1D structure the 3D local model obtained through our local inversion for crustal depths (Fig. 6c). To ensure a smooth transition between these two initial models, we proceed to some regularizations. We only consider the well-resolved part of the 3D local model, i.e. from the surface down to $40 \mathrm{~km}$ (Fig, 2). Because the horizontal extension of this well-resolved part is smaller than the regional velocity model (Figs. 1 and 6a), we smooth its lateral edges using Albaric et al. (2010 \& 2014) 1D model. Finally, we also introduce a vertical smooth transition at intermediate depths ( 40 and $80 \mathrm{~km})$ to avoid an abrupt boundary between the local heterogeneous model and IASP91 (Fig. S3). 
a) Model's grid in map view

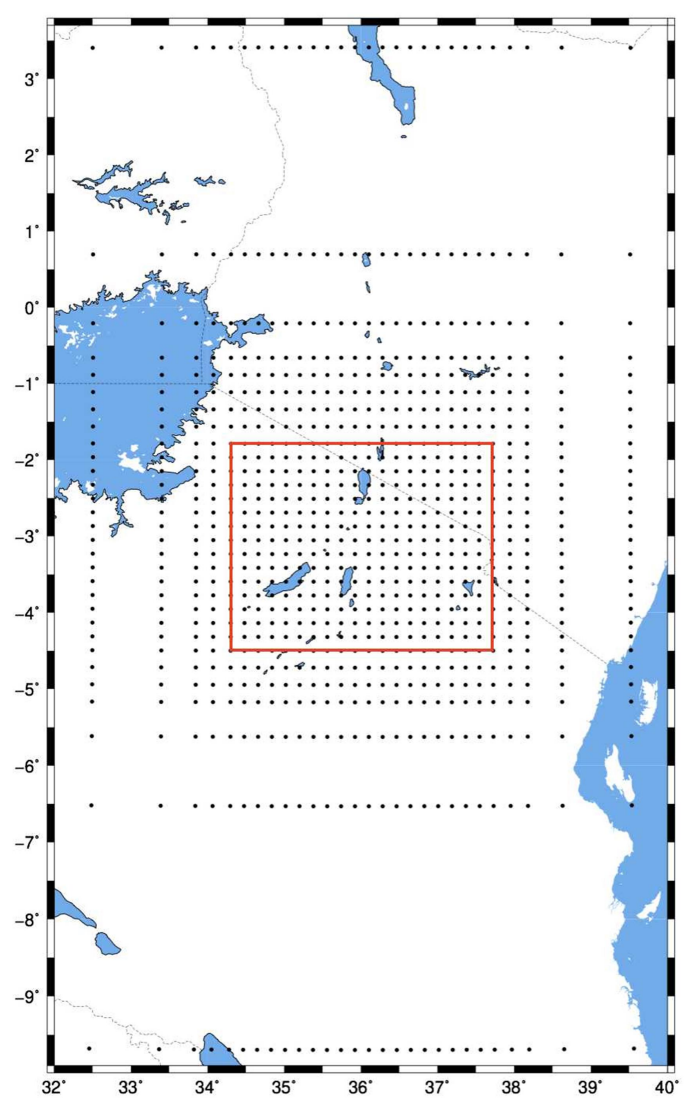

b) Model's grid in cross section

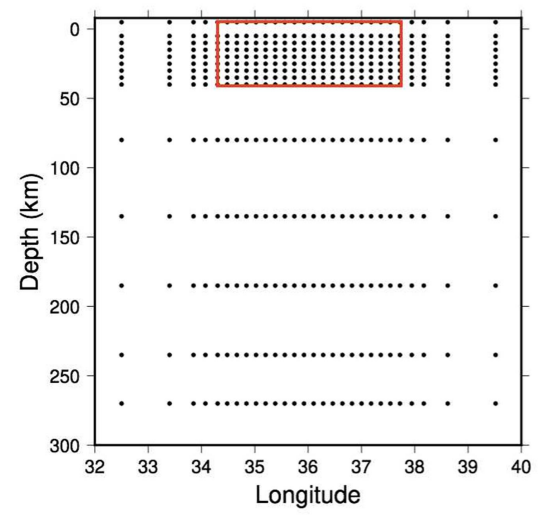

c) P wave starting velocity model

\begin{tabular}{|c|c|c|}
\hline Depth (km) & $V p(k m . s-1)$ & TFGLB Sv $\left(\mathrm{km} \cdot \mathrm{s}^{-1}\right)$ \\
\hline$[-5 ; 5[$ & 5,40 & 0,001 \\
\hline$[5 ; 10[$ & 6,00 & 0,001 \\
\hline$[10 ; 15[$ & 6,20 & 0,001 \\
\hline$[15 ; 20[$ & 6,35 & 0,001 \\
\hline$[20 ; 25[$ & 6,50 & 0,001 \\
\hline$[25 ; 30[$ & 7,00 & 0,003 \\
\hline [30;35[ & 7,35 & 0,006 \\
\hline [35;40[ & 7,90 & 0,01 \\
\hline$[40 ; 80[$ & $8, \overline{0}$ & 0,02 \\
\hline$[80 ; 135[$ & 8,07 & 0,02 \\
\hline$[135 ; 185[$ & 8,10 & 0,02 \\
\hline$[185 ; 235[$ & 8,22 & 0,02 \\
\hline [235;270[ & 8,39 & 0,02 \\
\hline [270;400[ & 8,52 & 0,02 \\
\hline$\geq 400$ & 8,99 & 0,02 \\
\hline
\end{tabular}

Figure 6: Configuration of the grid net in the horizontal (a) and vertical planes (b) for the constrained teleseismic inversion. The red boxes correspond to the limits of the local velocity model. The velocity values and the velocity standard deviation (for TFGLB, see text for explanations) corresponding to the grid's nodes are listed in the Table (c). Vahes indicated for -5 to $40 \mathrm{~km}$ are only the $1 \mathrm{D}$ model. (For comparison, the teleseismic T grid neths in Supplementary Material S4.)

The grid configuration is shown Fig. 6 and consists of a 3D non-regular grid of nodes. In order to account for the complexity of the velocity structure in the crust, the initial model was parameterized with a dense distribution of nodes down to $40 \mathrm{~km}$ depth and a coarser one below. Grid nodes at depth are located at $-5,5,10,15,20,25,30,35,40,80,135,185,235,270$ and $400 \mathrm{~km}$ (Fig. 6c). The velocity model is composed of 28 and 30 nodes in $\mathrm{x}$ and $\mathrm{y}$ directions respectively, corresponding to a surface coverage of $780 \times 1450 \mathrm{~km}^{2}$. The interval between horizontal nodes is 20 $\mathrm{km}$ regular in the central part alike the local tomographic model, but in contrast to the local 
tomography model, it progressively widens in the periphery (intervals from 20 to $350 \mathrm{~km}$ ). We choose this grid configuration in accordance with the resolution of the velocity structure and the ray coverage of each tomographic procedure. P-wave velocity is assigned to each node.

\section{Inversion process}

Our teleseismic inversion is based on Zeyen \& Achauer (1997) and Tiberi et al. (2003) and use the Steck \& Prothero (1991) raytracing. This iterative method is well-adapted for a regional network and allows for an adaptive crustal 3D heterogeneous model (Tiberi et al., 2003). A standard deviation value $\mathrm{Sv}$ is assigned to each node of the model, and controls the maximum variation from the velocity initial value through iterations. This approach also includes smoothing constraints and a priori data standard deviation $(\mathrm{Sd})$ to stabilize the inversion. The inversion proceeds until the sum

of the differences between observed and calculated data reaches a given threshold or when the maximum number of iterations is reached. At the end, we evaluate the efficiency of the inversion through the root mean square (RMS) decrease and the final distribution of the calculated data, which should be close to the observed one.

The optimal values of the smoothing parameter, the number of maximal iterations, threshold and the a priori data standard deviation were fixed by Tiberi et al. (2019) through various tests for the inversion process factors. The best values for these are 0.1 for the smoothing and $0.001 \mathrm{~s}$ for the time difference threshold. The data standard error was divided into four ranges, depending on the very good $(\mathrm{Sd}=0.05 \mathrm{~s})$, good $(\mathrm{Sd}=0.10 \mathrm{~s})$, moderate $(\mathrm{Sd}=0.15 \mathrm{~s})$ and bad $(\mathrm{Sd}=0.2 \mathrm{~s})$ delay-times quality. The number of iterations is set to 5, as no significant changes in the RMS decrease is noted after. We use the same set of parameters in all of our inversions.

Hereafter, we investigate the effect of this complex starting velocity model in the NTD lithospheric structure in comparison with the results obtained by Tiberi et al. (2019). In particular, we study two cases: a Teleseismic Finer Grid Local model (labelled TFGL), and a Teleseismic Finer Grid Local 
model with Blocked surface (labelled TFGLB). In the TFGL case, we introduce the 3D crustal model and allow it to vary during the inversion (smoothing $=0.1$, a priori velocity standard deviation $=0.02 \mathrm{~km} \cdot \mathrm{s}^{-1}$ ) for the whole model. In the TFGLB case, we freeze the crustal velocities to their initial values deduced from the 3D local tomography. In order to avoid any deviation for the input crustal velocity model, we assign the crustal nodes a lower a priori standard deviation compared to mantle ones $\left(0.001 \mathrm{~km} . \mathrm{s}^{-1}\right.$ vs $0.02 \mathrm{~km} . \mathrm{s}^{-1} 1$ respectively, Fig. $\left.6 \mathrm{c}\right)$. The crustal standard deviation progressively increases to avoid fabricated abrupt velocity changes between the crust and the mantle (Fig. 6c). We will refer to Tiberi et al. (2019) parametrization and results as a benchmark (labelled Teleseismic T).

\section{Resolution tests}

In order to evaluate the resolution of the teleseismic images related to the different starting models, we perform checkerboard tests (Figs. 7 and 8) using the real source/receiver configurations. Contrary to what is usually done in teleseismic studies (e.g. Bastow et al., 2005; Tiberi et al., 2019), we follow the same protocol described above in the local tomography part (Gautier et al., 2006). The checkerboard tests are carried out assigning small velocity perturbations to the final tomographic model. We consider the final tomographic model to evaluate the individual contributions of the $3 \mathrm{D}$ crustal structure and the shallower grid on the teleseismic resolution.

To construct the checkerboard, we add alternative positive and negative perturbations of $5 \%$ in one given layer of the final tomographic model. The input velocity anomalies are $2 \times 2$ or $3 \times 3$ nodes (i.e. $40 \times 40 \mathrm{~km}^{2}$ wide in the local part and $50 \times 50 \mathrm{~km}^{2}$ in the regional part; $60 \times 60 \mathrm{~km}^{2}$ in the local part and $75 \times 75 \mathrm{~km}^{2}$ in the regional part, respectively). We construct synthetic residual delay times by computing the difference of travel-times between rays that propagate in the final tomographic model and the same rays passing through the checkerboard model. Finally, we invert these synthetic data by using the same inversion process and parameters (velocity standard deviation of $0.02 \mathrm{~km} . \mathrm{s}^{-1}$, smoothing of 0.1 , no random noise) as Tiberi et al. (2019). We perform checkerboard tests in 
different layers located at crustal depth $(25 \mathrm{~km})$, mantle depths $(80$ and $135 \mathrm{~km})$, as well as at intermediate depth $(40 \mathrm{~km})$ to tackle the resolution close to the Moho discontinuity.

Figs. 7 and 8 show the checkerboard tests in horizontal map views and vertical cross-sections, respectively. The checkerboard pattern is well retrieved from $40 \mathrm{~km}$ depth down to $135 \mathrm{~km}$ for most of the study area. This means that the addition of the local a priori constraints in the initial 1D model does not damage the resolution of the inversion at mantle depth, compared to the initial parametrization of Tiberi et al. (2019). This also validates the parameterization we used in terms of smoothing and covariance factors, derived from Tiberi et al. (2019).

Concerning the crustal resolution of our new teleseismic inversion procedure $(25 \mathrm{~km}$ depth test for TFGL and TFGLB cases), the location of the velocity anomalies is correctly retrieved, while we reconstruct less than $50 \%$ of their initial amplitude. This result is independent of the crustal velocity model, demonstrating that the first layers remain poorly resolved even in the case of strong crustal constraints. As expected, the crustal part cannot be improved by teleseismic inversions when only considering teleseismic data. It then fully justifies to keep the 3D local tomography as the most relevant model for the shallowest part in teleseismic strategy on real data. We therefore choose to maintain the crustal velocity distribution unchanged during the inversion (i.e. TFGLB case).

For the mantle layers $(40,80$ and $135 \mathrm{~km})$, TFGL and TFGLB cases are both able to retrieve smaller size anomalies than the teleseismic case from Tiberi et al. (2019) $\left(40 \mathrm{x} 40 \mathrm{~km}^{2} v s 50 \times 50\right.$ $\mathrm{km}^{2}$ at $40 \mathrm{~km}$ depth respectively, Fig. 7 and S5). Both TFGLB and TFGL 2 x 2 nodes checkers produce similar results in terms of geometry and amplitudes (Figs. 7 and 8). The recovered amplitude ranges between -10 and $+10 \%$. The amplitudes are overestimated by $\pm 1-2 \%$ at $40 \mathrm{~km}$ and are up to $\pm 5 \%$ at $80 \mathrm{~km}$ depth. At 40 and $80 \mathrm{~km}$ depth, the finest resolution matches $40 \times 40 \mathrm{~km}^{2}$ bodies while, at $135 \mathrm{~km}$ depth, the smallest well-reconstructed anomalies coincide with the $60 \times 60$ $\mathrm{km}^{2}$ bodies $(3 \times 3$ nodes $)$. These anomaly sizes define the minimum anomaly size that is expected to be resolved in our tomographic inversions at the different depths. 


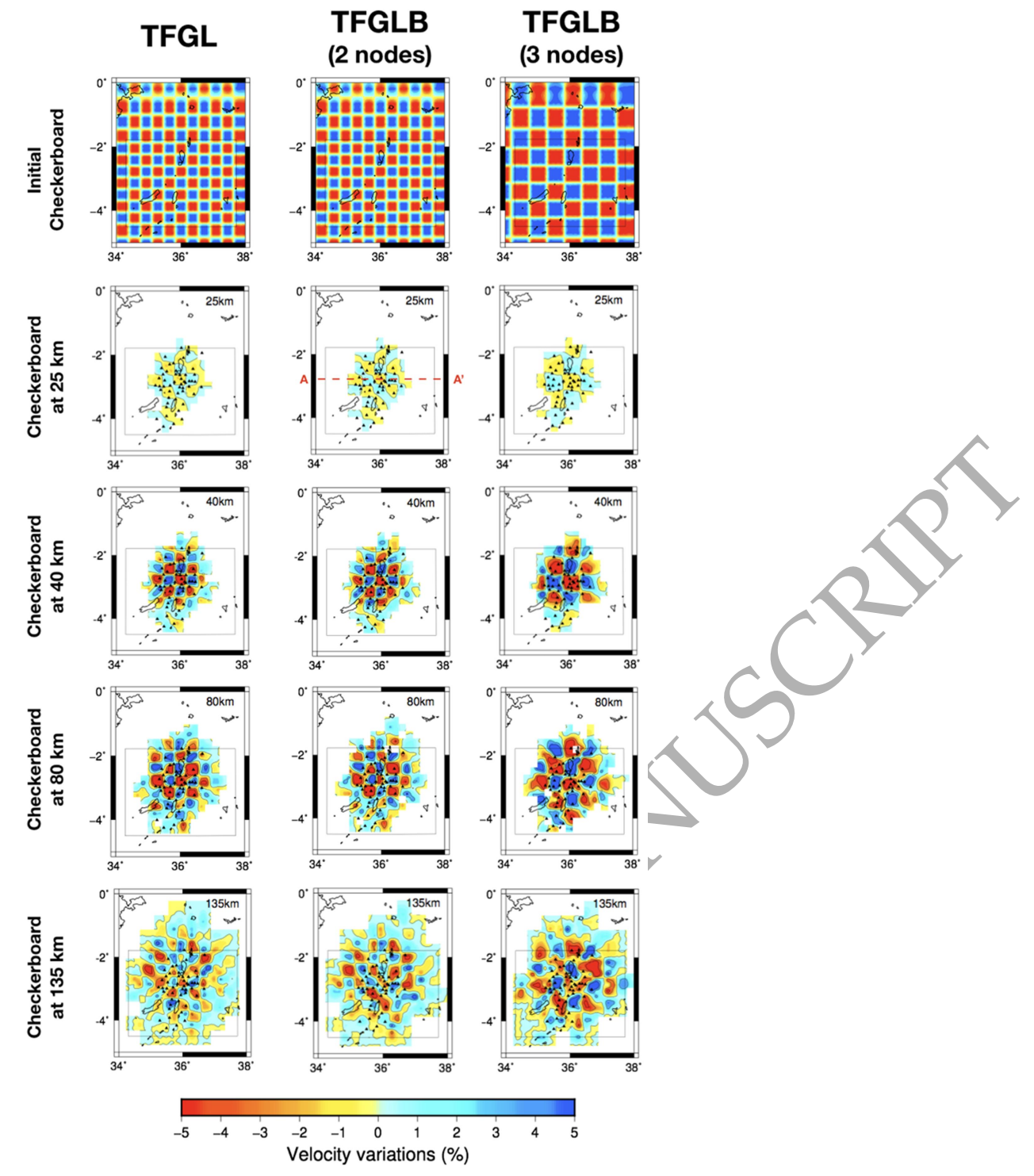

Figure 7: Checkerboard retrieved patterns in map view after P-waves tomographic inversions. The first row shows the true checkerboard anomaly added to the $3 D$ final velocity model. The left panel shows the results of the model induding the $3 D$ local velocity structure (TFGL). The central and right columns present the vesults of the model with local velocity structure and blocked surface (TFGLB) with $40 \times 40 \mathrm{~km}^{2}$ and $60 \times 60 \mathrm{~km}^{2}$ checkerboard size respectively. The rectangle delimits the local initial model The-isocontours mark the $-5,-3,0,3$, and 5\% velocity variations. The AA' red dashed line is the eross section track of Figure 8. 
When the local velocity structure is inserted in the first $40 \mathrm{~km}$ (both TFGL and TFGLB cases $v s$ TFG, see Fig. S6), the overall mantle resolution is improved as horizontal and vertical smearing is restricted. By fixing the starting crustal model during the inversion, the artefacts are not totally suppressed in the upper mantle but they are greatly reduced (see VSA label in Fig.8). These artefacts are located between 100 and $200 \mathrm{~km}$ for TFGL but they are restricted to $100-150 \mathrm{~km}$ depth for TFGLB. The amplitude of the artefacts is also reduced by about $2 \%$ in TFGLB compared to TFGL (see VSA label by example, Fig. 8). Eastward, the remaining artefact VSA could result from an inhomogeneous azimuthal source distribution, with the largest number of events coming from South-East Asia (Tiberi et al., 2019), combined with the poor resolution of the local velocity model in this area (Fig. 2).

From the synthetic tests, we conclude that the use of an a priori $3 \mathrm{D}$ crustal structure reduces the vertical smearing effect and allows to image smaller structures than a classic teleseismic case for intermediate depths (Tiberi et al., 2019). Because we use a hybrid method with a teleseismic inversion (nearly vertical rays) instead of a joint inversion (teleseismic and local travel-time simultaneously inverted), we still have a lack of crustal resolution. In order to take into account these different aspects, we propose a hybrid teleseismic approach considering a strong crustal constrain, i.e. the TFGLB case with a crustal model which stays unchanged during the inversion (Fig. 6c). The crustal part will then only be constrained from the local inversion and will give the best result for the corresponding depths (Fig. 2). The mantle part on the other hand will benefit from the constrained crust with réduced smearing effects and a better structure delimitation. 
TFGL
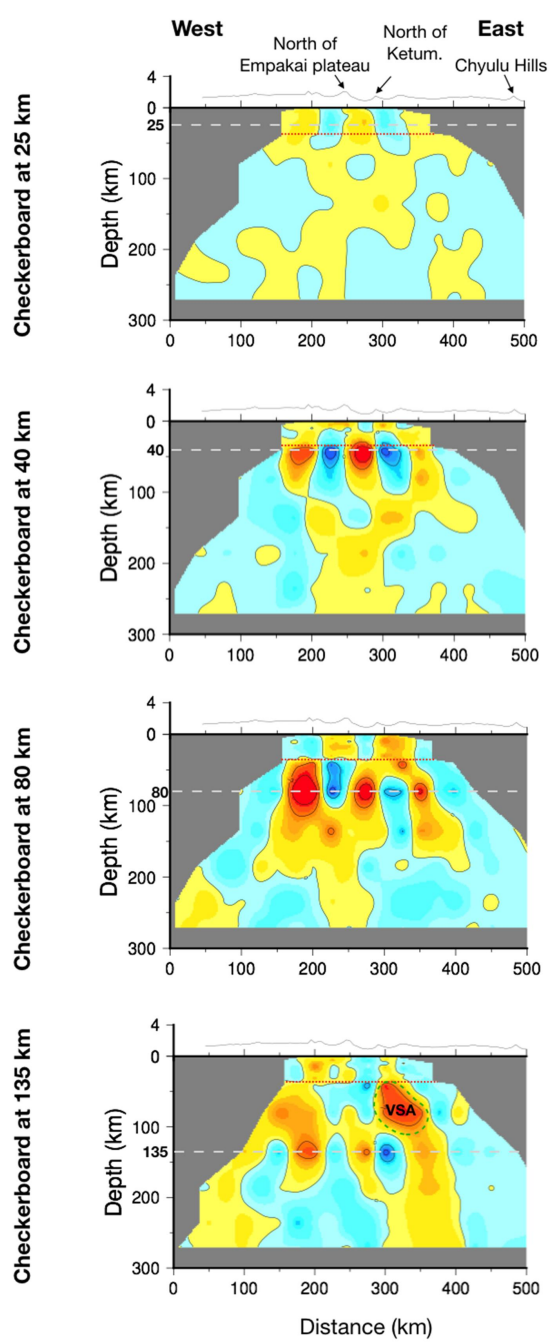

TFGLB (2 nodes)
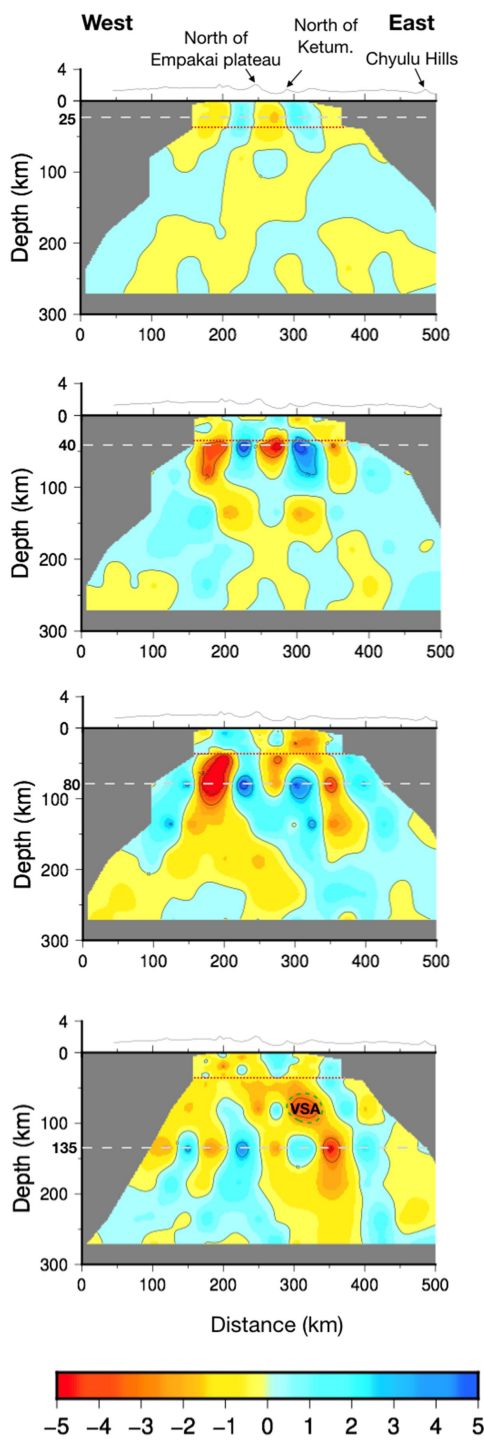

Velocity variations (\%)
TFGLB

(3 nodes)
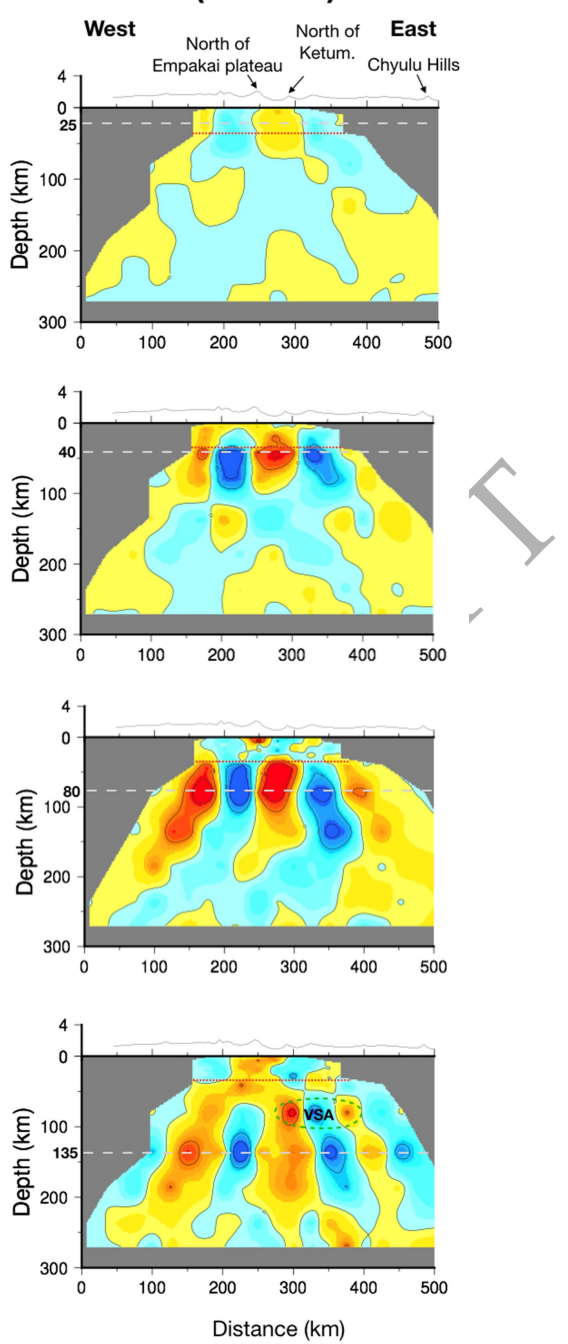

Figure 8: P-waves checkerboard tests results in a West-East cross-section (latitude $-2.8^{\circ} \mathrm{S}, \mathrm{AA}$ ' in Fig.7). Left: starting modet including the local velocity structure (TFGL). Centre and right: starting model with local velocity structure and blocked surface (TFGLB), with $40 \times 40 \mathrm{~km}^{2}$ and $60 \times 60 \mathrm{~km}^{2}$ checkerboard anomahes respectively. The red dotted line delimits the local initial model. The grey dashed line marks the input velocity anomalies depth. Green dashed circles highlight the velocity smearing area (VSA) discussed in the text. The isocontours mark the -5, -3, 0, 3, and 5\% velocity variations. Ketum. abbreviation stands for Ketumbeine volcano. 


\section{Application to the NTD}

Our hybrid teleseismic inversion (TFGLB) produces satisfying RMS decrease through iterations (31.65\%), though slightly lowered compared to the classical teleseismic $(\mathrm{T})$ procedure $(41.22 \%)$ (Figs. 9b and 9d respectively). The lower reduction in misfit value for the TFGLB inversion is due to the strong imposed crustal constraints, that restricts the fit of the delay-times for the crustal part. This is noticeable through the $41.59 \%$ of RMS reduction in the TFGL case (Fig. S7), where the crustal part is not fixed. However, the good data variance recovery $(72.20 \%$ for TFGLB and 83.39\% for TFGL) associated with the checkerboard tests suggests that TFGLB inversion gives an overall good fit for the mantle.

First, the resulting TFGLB images are consistent with the results obtained by Tiberi et al., (2019) for the long wavelength, with a main low velocity zone (Figs. 9d for T case and $9 \mathrm{~b}$ for TFGLB, labelled LV1) located in the central part of the model, that extends from the bottom up to the surface of the velocity model. This low velocity central part is flanked by two high velocity anomalies, annotated HV1 and HV2, that are restricted to the first 100-120 km depth. It is worth noticing that the crustal part and the mantle part, obtained from an independent dataset inversion (local vs teleseismic), are very coherent in shape and amplitude and display continuous structures on both sides of the Moho interface. 
a) TFGLB $-2.6^{\circ} \mathrm{S}$

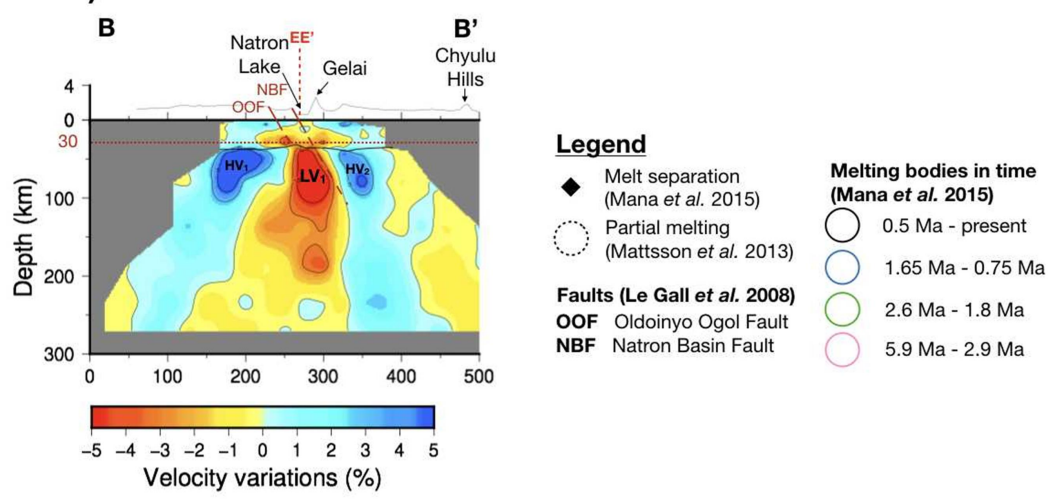

b) TFGLB $-2.76^{\circ} \mathrm{S}$

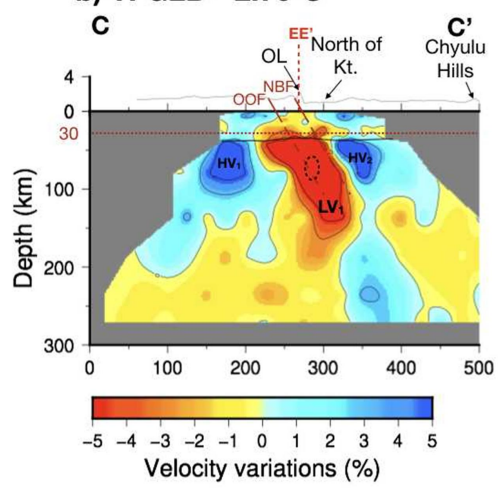

C) TFGLB $-3.2^{\circ} \mathrm{S}$

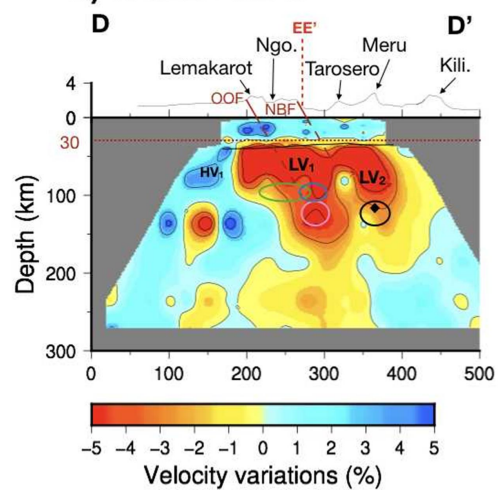

d) $\mathrm{T}-2.76^{\circ} \mathrm{S}$

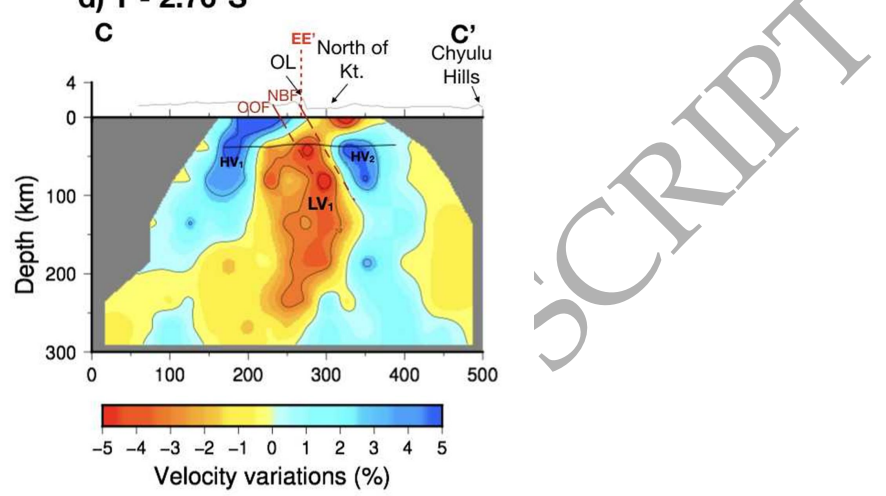

e) TFGLB - $35.9^{\circ}$

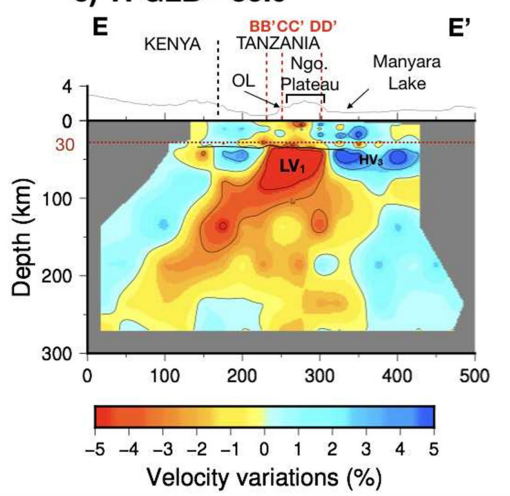

Figure 9: West-East (a to $d$ and North-South (e) cross sections through the P-wave classical teleseismic (T) and hybrid teleseismic (TFGLB) models. The cross-section tracks are localized Fig. 5. $H V$ stands for High Velocity anomaly and LV for Low Velocity anomaly referred to in the text. The red dotted line delimits the base of the fixed local model, which is frozen in the hybrid teleseismic inversion. The thin subhorizontal black line represents Moho depth from Plasman et al. (2017). Voleanic edifices: Kili. - Kilimanjaro; Kt. - Ketumbeine; Ngo. - Ngorongoro; OL - Ol Doinyo Lengai. Faults (vertical exaggeration): OOF; Ol Doinyo Ogol Fault; NBF Natron Basin Fault. Inferred partial mélting zones from Mana et al. (2015) and Mattsson et al. 2013. 
Despite the same regional mantle structure, substantial changes happen for short wavelengths when the hybrid procedure is used. In particular, the continuity of mantle structures within the crust is modified. The connection of the central low velocity with the surface is clearly sharpened, and appears with enhanced details. This results in a transfer of the amplitude to the upper mantle, where low anomalies between 50 and $100 \mathrm{~km}$ depth are amplified by 3\% on average (Figs. 9d and 9b). The shape, and in particular the boundaries, of the central low velocity zone are also modified and present a strong 3D pattern, as first suggested in Tiberi et al. (2019). Our results expand this observation and allow us to discuss the geometry of the velocity anomalies from the upper mantle upward the surface.

In the upper mantle, the main change is the restriction of the low velocity zone up to $150 \mathrm{~km}$ depth, and its widening as we follow it southward. In particular, its west-dipping tip, that is present in T case between $200 \mathrm{~km}$ and $250 \mathrm{~km}$ depth, disappears when considering a 3D local a priori model for the crust (Figs. 9d and 9b). Our tomographic results also make the 3D structure of the central low velocity zone clearer for intermediate depths. This anomaly, that is centred beneath the axial rift valley with a rough N-S direction at $135 \mathrm{~km}$ depth, splits in two distinctive anomalies (LV1 and LV2, Fig. 10), with NE-SW strikes from $80 \mathrm{~km}$ depth. Close to the Moho boundary, the two lowvelocity zones LV1 and LV2 correlate with the Ngorongoro and Meru volcanic complexes, respectively. In particular, LV2 is perfectly restricted to the Meru-Monduli-Burko-Essemingor volcanic complex, with a maximum amplitude (-8\%) beneath the Meru edifice. LV1 extends below the Ngorongoro complex until the Gelai and Ketumbeine edifices boundary. We notice that the amplitude (from $-4 \%$ in the rift axis to $-12 \%$ below the Ngorongoro crater) and the maximum depth of these two low-velocity anomalies agree with petrological and geochemical constraints and partial melt depth (Mana et al., 2015; Mattsson et al., 2013) (Fig. 9c). This emphasizes that our tomographic images can be used to characterize the geometry of melt zones at a lithospheric scale, even in areas with no current volcanism. Moreover, our images point out that the top of these two low-velocity anomalies coincides with the Moho interface, which was determined with an 
independent receiver function method (Plasman et al., 2017). This correlation implies a strong lithological control on the vertical extension of these low-velocity anomalies towards the surface (i.e. magma ascending), probably related to a significant strength of the crust down to lower crustal layers (Albaric et al., 2010).

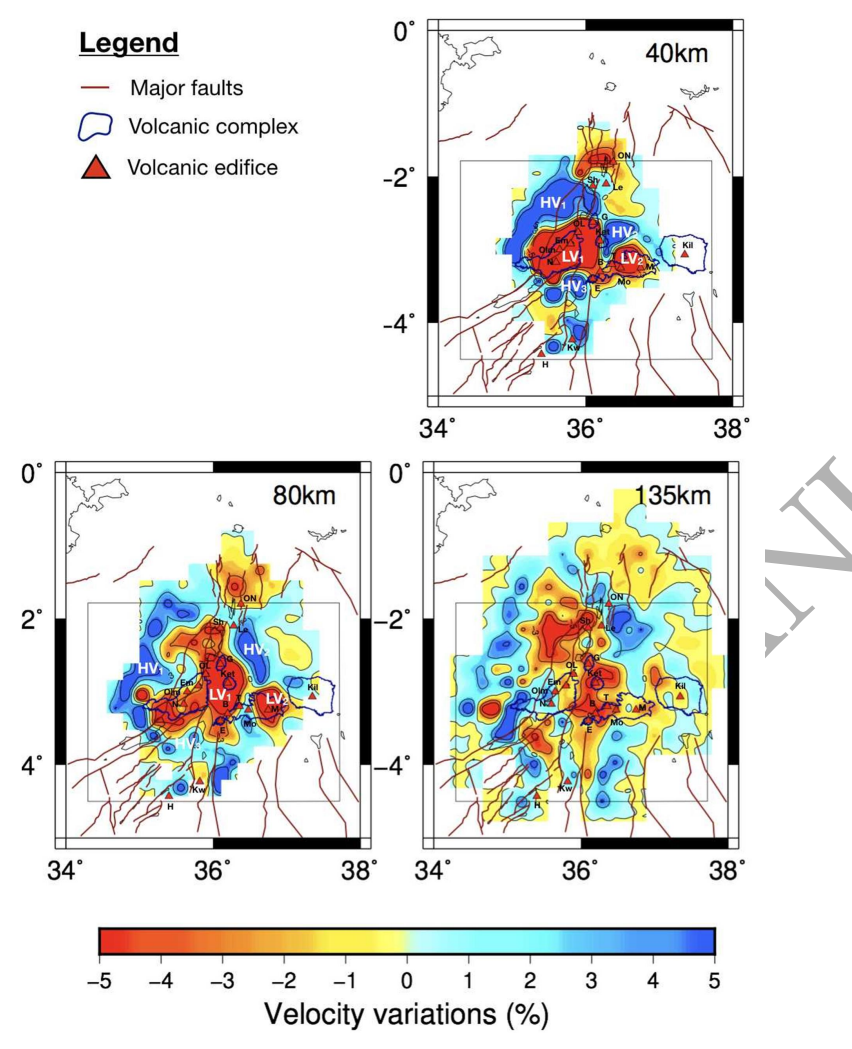

Figure 10: P-waves inversion mapkriens of the Teleseismic with a Finer Grid, the Local data and Blocked velocity (TFGLB) model. The black box delimits the horizontal extension of the local model at the surface. HV stands for High Velocity anomaly and LV for Low Velocity anomaly, referred to in the text.

LV1 and LV2, zones are separated by a positive anomaly (HV3) centred below Manyara basin and that extends from the surface down to $70 \mathrm{~km}$ depth (Figs. 9e and 10). HV3 is consistent with a 50 km-thick well resolved electrically resistive unit (Plasman et al., 2019) and correlates with the surface expression of the northern edge of the Masai block. The depth resolution of our 3D velocity 
model assesses a clearer velocity contrast, delimiting a more precise thickness of this lithological unit. Moreover, this massive high-velocity anomaly confirms that the Masai block corresponds to a strong, and probably cratonic, lithological unit (Albaric et al., 2010 \& 2014), which seems to act as a barrier between the two low-velocity zones. Considering the lithospheric images and this massive high-velocity zone, we rather relate the lower-crustal earthquake swarm south of Manyara lake (Fig. 5) to fluid pressures coming from deeply rooted magmatism along pre-existing fabrics, as first proposed by Albaric et al. (2014).

In addition to the imaging of the melt zones, one other notable result of our inversion is the wellresolved geometry of the accreted Panafrican lithological units, and in particular the related boundaries between the Tanzanian craton (HV1), the Mobile Belts (HV2) and the rift zone (LV1). Indeed, the contact between the central low-velocity anomaly (LV1) displays an eastern dip, which becomes more pronounced going southwards (from $0^{\circ}$ to $65^{\circ} \mathrm{E}$ ) (Figs. 9a, 9b, 9c). Our images point out that the geometry of LV1 at depth matches some main tectonic structure at the surface, and in particular the location, the dip and the orientation of the Ol Doinyo Ogol (OOF) and Natron Border (NBF) (Le Gall et al., 2008; Fritz et al., 2013) (Figs. 9a to 9c). This suggests that the surface expression of the mechanical deformation related to the rift development is strongly related to inherited structural heterogeneities of the basement Finally, at intermediate depth, the eastern edge of HV1 show strong lateral variations from north to south, denoting an initial heterogeneous geometry of the Tanzanian craton unit when it collided during Panafrican orogenies, or a possible post-Panafrican collision erosion of this inherited structure (Currie \& Van Wijk, 2016).

\section{Discussion}

In this study, we present a hybrid approach to invert teleseismic travel-times by integrating strong crustal constraints. This new method allows us to enhance depth resolution in teleseismic images, in particular at the Moho discontinuity. This is mandatory to investigate crustal and mantle processes, 
their continuity and their relationships or interactions. Tested on a complex geodynamic area, the NTD area, the resulting model offers a continuous and coherent view of anomalous velocity zones or structures at crust-to-upper mantle depths.

\subsection{Effect of 3D crustal structure in teleseismic images}

Zhao et al. (1994) and Roecker et al. (1993) realized joint inversions of local and teleseismic data sets with a 1D a priori model. It allowed them to increase the ray coverage and to obtain clearer images of the upper mantle. Contrary to these studies, we performed a constrained teleseismic inversion using independently use the local and teleseismic data sets in a hybrid approach. We insert a 3D well-resolved crustal velocity structure in the initial lithospheric model and then only invert the teleseismic travel-times to image the upper mantle. Our ray coverage is not broadened, but the addition of the 3D fixed structure improves the resolution in the upper mantle while maintaining a well-defined crustal velocity structure. This shows that our hybrid tomographic approach benefits from both datasets without deprecating their respective resolution.

Our synthetic tests and inversions on real data demonstrate that both finer shallower grid and crustal velocity structure have strong effects on teleseismic images. Fixing the crustal part during the inversion diminishes the vertical downward smearing and reduces the artefacts in the crust. We also sharpen anomaly boundaries and increase their amplitude. This is consistent with the results obtained by Waldhauser et al. (2002) and Sandoval et al. (2003) who constructed a 3D crustal starting model based on previous studies (Moho topography, sedimentary basin, known crustal structures), applied a time correction for crustal effects and blocked the crustal part during their

inversion. They underlined a reduction of the artefacts and a better location of the velocity anomalies in the upper mantle. On the contrary, our conclusions differ from Martin et al. (2005), who mention an important leakage within the mantle part of their model, that we do not have in our study. Our study points out that similar and convincing tomographic results can be obtained without complex crustal time correction. By restricting the number of crustal corrections, our approach 
limits the contamination of inappropriate signals within the mantle and avoids interpretation of artefact or fake crustal signal.

\subsection{Role of magmatism and inherited structure in the NTD}

Our hybrid inversion offers a good resolution at both crustal and lithospheric depths, and new constraints close to the Moho boundary. The continuous and well-resolved images for the NTD region allow the investigation of melt zones, their relation with deep seated processes, mantle dynamic and inherited structures. We hereafter question the role of inherited structures on the location of the deformation at the surface, the interplay between faults and magmatic intrusion, and the depth location of melt.

\section{Lateral control from inherited structures}

Our results shed light on the similarity between major fault directions (OOF, NBF), main volcanic features at the surface (Ngorongoro, Meru, dyke intrusion, Calais et al., 2008) and the lithospheric anomaly orientations at intermediate depth (i.e. near the Moho, at 40-80 km depth) (Fig. 9). This observation illustrates the impact of ancient and inherited structures on the location of crustal deformation. Recent analogue experiments show that pre-existing weakness zone in the lithosphere will accommodate the regional stress through localized brittle deformation in the upper crust, while the absence of pre-existing structure results in a more distributed deformation at the surface (Santimano \& Pysklywec, 2020). These pre-existing structures can either be ancient sutures between units, or have deyeloped during past orogenic events (Vauchez et al., 1998). In our case, Neoproterozoic collisional events that have formed the Mozambique Belt (Shackleton, 1986; Key et al., 1989) may also have produced a lithospheric coherent fabric, which could remain frozen in the mantle. This N-NE trending pervasive fabric is coherent with the sparse SKS splitting measurements available in the region (Gao et al., 1997; Barruol \& Ben Ismail, 2001; Walker et al., 2004; Albaric et al., 2014) However, the anisotropy recorded through the SKS analysis 
encompasses combined effect of the pre-existing structures of the lithospheric mantle as well as melt pockets alinement and asthenospheric flow. These three processes are highly probable in the region (Vauchez et al., 2000). Only a thorough and detailed analysis of new SKS data would help to discern those effects.

Our models support the idea of such an interplay between major old suture zones and asthenospheric material (Fig. 11). The Ngorongoro area is the result of the interaction between the old craton/mobile belt suture and the mantle plume. The lithological discontinuity between the Tanzanian craton and the Mozambique Belt may have played the role of such a weakness zone. As mantle upwelling preferentially migrate and break through the weaker part of the lithosphere (Koptev et al., 2016), this past suture has strongly influenced the location of upper mantle slow velocity anomalies and shaped its volume. Ultimately, this deep pre-existing suture orientation has been transmitted towards the surface and guides the brittle deformation in the upper crust. The emplacement of first magmatic expressions (Sadiman and Essimingor volcanic edifices, Mana et al., 2012 \& 2015) was focused on the region where cratonic units (Tanzanian Craton, Masai block) meet the mobile belt (Corti et al., 2007). 

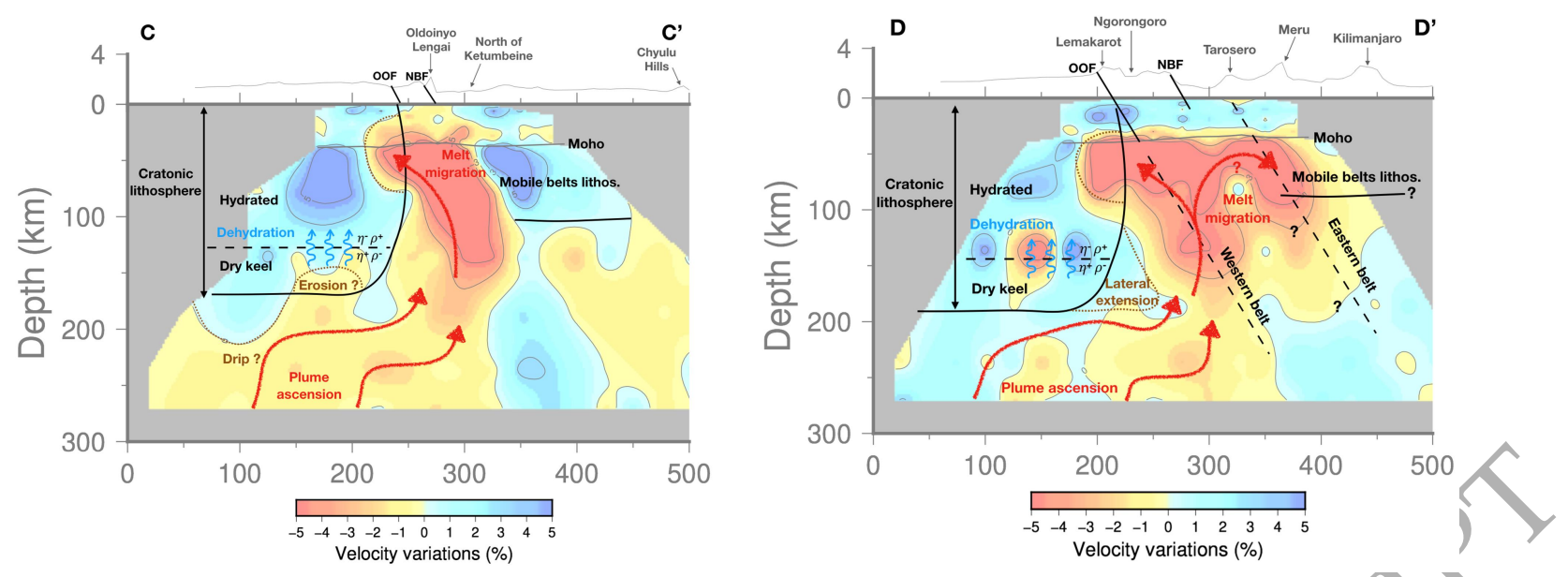

Figure 11: Schematic illustration of our geodynamic scenario. The plume ascent, blocked betow the craton, bypasses the cratonic rigid lithosphere on its eastern side. The rise of temperature at the craton base induces a dehydration of the keel, and thus a viscosity ( $\eta)$ increase and a density ( $\rho$ ) decrease. The craton becomes more stable against mantle erosion while its upper part of the cratonic lithosphere remains hydrated. In the first $100 \mathrm{~km}$, the melt overtakes temperature effect (Tiberi et al., 2019, Soltanmohammadi et al., 2018) and migrates in pre-existing heterogeneities, explaining the highly 3D images in tomography. The cross-section tracks are localized Fig. 5.

\section{Rheological vertical control}

Even though pre-existing mantle-lithospheric heterogeneities participate, the vertical stratified rheology of lithosphere remains an important factor in the location of the deformation (Ziegler \& Cloetingh, 2004; Burov 2011). The thermo-mechanical structure of the lithosphere affects both the geometry of the crustal deformation and the vertical dynamic of upper mantle processes (Buck, 1991; Gueydan et al., 2008). The Moho plays an important role in this stratification and rheology control, as a major compositional and thermal boundary (Burov \& Diament, 1995; Cloetingh et al., 2013) The mechanical strength of the lithosphere is also influenced by its age, composition and thickness (Burov \& Diament, 1995). 
In our case, the old and thick African cratonic lithosphere has been for long associated with stronger and rigid rheology (Ebinger et al., 1997; Albaric et al., 2009). It is therefore more prone to sustain distributed deformation rather than localized one (Corti et al., 2013). Where the cratonic lithosphere is still intact, our models show a homogeneous high velocity and a rather flat and deep Moho. This is particularly the case in the region of the Masai block, strongly contrasting with low velocity lithospheric zones north of latitude $3.2^{\circ} \mathrm{S}$ (Fig. 9, EE'). The stiff Masai block creates a heterogeneity in the rheology of the lithosphere and modifies the way the crust is deforming. South of $3.2^{\circ} \mathrm{S}$, it results in a widening of the rift associated with a deep clustered seismicity in the Manyara Basin (Albaric et al., 2010, Figs. 3 and 5), and very recent (0.4-0.9 Ma), sporadic and less volumetric volcanic episodes (Baudouin 2016; Baudouin \& Parat, 2020). Rather than reflecting a weak mantle rheology (Gueydan et al., 2008), the distributed deformation and poor magmatic style of the Manyara Branch alternatively comes from a local change in the lithospheric strength. Our results beneath the Masai block, together with previous geophysical studies (Albaric et al., 2010; Plasman et al., 2019) advocate for a rheological resistant mafio lower crust and a more viscous lithosphere (Selway, 2015; Perez-Gussinye et al., 2009), blocking the southward propagation of the rift and the ascent of melt to the surface.

\section{Dynamic mantle processes}

The heterogeneity of the lithosphere combined with its rigid rheology distributes the surface deformation. The cornerstone of this concept is the Masai Block, which obstructs the southward propagation of the Kenyan rift (opening the Manyara and Pangani rift segments on both side of the Masai Block), and constrains the magmatic material to ascend along the suture of the Masai block and Tanzanian Craton. As a consequence, the earliest and major volcanic complexes have emerged on its edges: the Ngorongoro and the Essemingor-Meru volcanic centres. The Masai lithospheric unit also acts as a strong rheological barrier, preventing from a localised rift opening and resulting in a scattering surface deformation in 3 branches (Eyasi, Manyara and Pangani from West to East respectively). The magmatic intrusions that developed at the Western and Northern Masai block 
edges weaken the strong cratonic lithosphere and allow for faults to propagate (Buck, 2006). The faults orientations are influenced by ancient and deeper lithospheric structures, explaining the similarity of their N-S and NE-SW strikes with the main upper mantle low velocity bodies geometry (Fig. 9, 40 to $150 \mathrm{~km}$ depth). This clearly demonstrates the impact of deep-seated processes on surface features.

The high contrast between positive and negative seismic anomalies we image beneath the NTD at lithospheric depth $(50-150 \mathrm{~km})$ advocates for chemical and compositional modifications of the lithosphere in addition to thermal alteration. The presence of melt in the lithosphere $(\mathrm{Vp} \geq 10 \%$ in Figs. 9 and 10, as proposed by Soltanmohammadi et al., 2018) is favoured by the hydration (Baptiste et al., 2015) and carbonation of the lithosphere in this region (Muirhead et al., 2019), both decreasing the solidus (Foley 2008). The presence of a metasomatized mantle may have promoted the production of carbonated melt (Rudnick et al., 1993; Soltanmohammadi et al., 2018). This thermochemical erosion eases the process of lithospheric thinning and can explain its higher value ( $\sim 60 \mathrm{~km})$ compared to crustal thinning $(\sim 10 \mathrm{~km})$ in the case of the NTD (Fishwick, 2010; O’Donnell et al., 2013; Plasman et al., 2017; Tiberi et al., 2019; Accardo et al., 2020). Given the sharp and clear 3D geometry of our low velocity anomalies beneath the NTD, the alteration of the lithosphere is not uniform. It clearly indicates a mantle dynamic control in the region, or preexisting heterogeneities to localize the erosion. An abrupt change in lithospheric thickness such as observed at craton edge can trigger edge-driven convection, which in turn can erode the lithosphere or modify its pattern (Hardebol et al., 2012, Liu \& Chen, 2019). In the case of the Tanzanian Craton, its hydration, buoyancy and composition inhibit a mantle downward flow and rather advocate for an upward advection of the Archean mantle (Currie \& Van Wijk, 2016; Liu \& Chen, 2019). This explain the preserved high velocity anomaly associated to the Archean craton (Fig. 11). In the NTD case, the ascending material from the plume locally modifies the hydration state of the cratonic lithosphere, making it more or less resistant to mantle erosion (Selway et al. 2014; Currie \& van Wijk 2016). In the first $100 \mathrm{~km}$, melt associated to metasomatized mantle overtakes the 
temperature effect (Tiberi et al. 2019, Soltanmohammadi et al., 2018). Pre-existing structural and compositional heterogeneities localize the melt and control the occurrence of surface volcanism.

In this proposed frame, Manyara is then the expression of the ultimate control of inherited lithospheric structure and thermochemical process. The rigid Masai unit combined with a thick, probably mafic, crust completely prevents from the development of surface volcanism in this rifting onset context. It results in a deep-seated magmatism and clustered seismicity due to fluids overpressures in the lower crust. The lithosphere has still kept here its original strength and it explains the contrasted geophysical signature of this region compared to the Natron-Magadi branch.

\section{Conclusion}

We developed a new hybrid tomographic method by inserting an a priori 3D local model in a 1D layered lithospheric model and by fixing the crust during the teleseismic inversion. We then obtained new tomographic images with enhanced resolution for intermediate depth $(40-80 \mathrm{~km})$ and better-defined anomaly boundaries.

The strong horizontal gradient between the central negative and the lateral positive velocity anomalies marks the lithological contacts between the Tanzanian Craton, the Masai Block and the Proterozoic Belts. These sutures between inherited units act as weakness zones that guide mantle upwelling and localize the volcanism and the brittle surface deformation along preferential directions (major normal faults like OOF, NBF, MBF, PBF).

Meanwhile, the inherited structures contribute to the divergence of the deformation South of Natron-Magadi rift branch by changing the rheology of the lithosphere. The rigid Masai Block inhibits the southward rift propagation and compels the deformation to circumvent it. Its stiff rheology prevents the magmatism from reaching the surface, which results in a deep-seated magmatism associated with clustered seismicity in Manyara rift Branch. 
The Moho is seen as a major rheological interface, which strongly limits the mantle ascending material. Major magmatic bodies are mostly confined to the upper mantle and laterally extend below the Moho. This results in a thermomechanical alteration of the lithosphere, which has been unevenly distributed and framed according to pre-existing heterogeneities.

\section{Acknowledgments}

The data were collected thanks to CoLiBrEA (ANR-12-JS06-0004) ANR, CRAFTI (NFS-EAR1261681) and HATARI INSU-Tellus (2017-2018) fundings. This work was conducted with approval by the Commission for Science and Technology (COSTECH, Tanzania). We are grateful for logistical support from Tanzania National Parks Commission and the Ngorongoro Conservation Area which provided full access and authorizations to the sites. We could not have achieved this work without logistical assistance from primary and secondary school teachers throughout the region, the Masai clans in Tanzania, driver-guides from Fortes Tours, Tanapa and the French Embassy. Then we want to thank all the CoLiBrEA, Crafti and Hatari team members. Figures are designed through GMT software.

We deeply thank J.P. O'Donnell and an anonymous reviewer for their thorough reviews, which greatly helped to improve the manuscript. We gratefully acknowledge the suggestions and comments provided by J. Albaric, J. Deverchère, C. Ebinger, M. Plasman and the two reviewers from the precedent version of this paper.

\section{References}

Accardo, N.J., Gaherty, J.B., Shillington, D.J., Hopper, E., Nyblade, A.A., Ebinger, C.J., Scholz, C.A., et al. (2020) Thermochemical Modification of the Upper Mantle Beneath the Northern 
Malawi Rift Constrained From Shear Velocity Imaging. Geochemistry, Geophys. Geosystems, 21, 1-19. doi:10.1029/2019GC008843

Adams, A., Miller, J., \& Accardo, N. (2018). Relationships between lithospheric structures and rifting in the East African Rift System: A Rayleigh wave tomography study. Geochemistry, Geophysics, Geosystems, 19, 3793-3810. https://doi.org/10.1029/2018GC007750

Aki, K. \& Lee, W.H.K. (1976). Determination of Three-Dimensional Velocity Anomalies Under a Seismic Array Using First P Arrival Times From Local Earthquakes - 1. a Homogeneous Initial Model. J Geophys Res, 81, 4381-4399. doi:10.1029/JB081i023p04381

Albaric, J., Déverchère, J., Perrot, J., Jakovlev, A. \& Deschamps, A. (2014). Deep crustal earthquakes in North Tanzania, East Africa: Interplay between tectonic and magmatic processes in an incipient rift. Geochemistry, Geophys. Geosystems, 15, 374-394. doi:10.1002/2013GC005027

Albaric, J., Déverchère, J., Petit, C., Perrot, J. \& Gall, B. Le. (2009) Crustal rheology and depth distribution of earthquakes: Insights from the central and southern East African Rift System. Tectonophysics, 468, 28-41, Elsevier B.V. doi:10.1016/j.tecto.2008.05.021

Albaric, J., Perrot, J., Déverchère, J., Deschamps, A., Gall, B. Le, Ferdinand, R.W., Petit, C., et al. (2010). Contrasted seismogenic and rheological behaviours from shallow and deep earthquake sequences in the North Tanzanian Divergence, East Africa. J. African Earth Sci., 58, 799-811, Elsevier Ltd. doi:10.1016/j.jafrearsci.2009.09.005

Baer, G., Hamiel, Y., Shamir, G., Nof, R. (2008). Evolution of a magma-driven earthquake swarm and triggering of the nearby Oldoinyo Lengai eruption, as resolved by InSAR, ground observations and elastic modeling, East African Rift, 2007. Earth Planet. Sci. Lett., 272, 339352. doi: $10.1016 /$ j.eps1.2008.04.052

Baptiste, V., Tommasi, A., Vauchez, A., Demouchy, S. \& Rudnick, R.L. (2015) Deformation, hydration, and anisotropy of the lithospheric mantle in an active rift: Constraints from mantle 
xenoliths from the North Tanzanian Divergence of the East African Rift. Tectonophysics, 639, 34-55, Elsevier B.V. doi:10.1016/j.tecto.2014.11.011

Barruol, G. \& Ismail, W.B. (2001) Upper mantle anisotropy beneath the African IRIS and Geoscope stations. Geophys. J. Int., 146, 549-561. doi:10.1046/j.0956-540X.2001.01481.x

Bastow, I., G. Stuart, J.-M. Kendall, and C. Ebinger (2005), Upper-mantle seismic structure in a region of incipient continental breakup: northern Ethiopian rift, Geophys. J. Int., 162(2), 479493, doi:10.1111/j.1365-246X.2005.02666.x.

Baudouin, C. (2016) Volcanisme alcalin à l'initiation de la rupture continentale Rift Est Africain, Nord Tanzanie, bassin de Manyara.

Baudouin, C., \& Parat, F. (2020). Phlogopite-olivine nephelinites erupted during early-stage rifting, North Tanzanian Divergence. Frontiers in Earth Science, 8, 277.

Baudouin, C., Parat, F., Denis, C.M.M. \& Mangasini, F. (2016). Nephelinite lavas at early stage of rift initiation (Hanang volcano, North Tanzanian Divergence). Contrib. to Mineral. Petrol., 171, 1-20, Springer Berlin Heidelberg. doi:10.1007/s00410-016-1273-5

Biggs, J., Chivers, M. \& Hutchinson, M.C. (2013). Surface deformation and stress interactions during the 2007-2010 sequence of earthquake, dyke intrusion and eruption in northern tanzania. Geophys. J. Int., 195, 16-26. doi:10.1093/gji/ggt226

Birt, C.S., Maguire, P.K.H., Khan, M.A., Thybo, H., Keller, G.R. \& Patel, J. (1997) The influence of pre-existing structures on the evolution of the southern Kenya Rift Valley - Evidence from seismic and gravity studies. Tectonophysics, 278, 211-242. doi:10.1016/S0040-1951(97)00105-4

Brune, S. (2016) Rifts and Rifted Margins: A Review of Geodynamic Processes and Natural Hazards. Plate Boundaries Nat. Hazards, 11-37. doi:10.1002/9781119054146.ch2

Buck, W.R. (1991) Modes of Continental Lithospheric Extension. J. Geophys. Res., 96, 20161. doi:10.1029/91JB01485 
Buck, W.R. (2006) The role of magma in the development of the Afro-Arabian Rift System. Geol. Soc. Spec. Publ., 259, 43-54. doi:10.1144/GSL.SP.2006.259.01.05

Burov, E. \& Poliakov, A. (2003) Erosional forcing of basin dynamics: New aspects of syn- and post-rift evolution. Geol. Soc. Spec. Publ., 212, 209-223. doi:10.1144/GSL.SP.2003.212.01.14

Burov, E.B. (2011). Rheology and strength of the lithosphere. Marine and Petroleum Geology, 28(ㅁ), p1402-1443 https://doi.org/10.1016/j.marpetgeo.2011.05.008

Burov, E.B. \& Diament, M. (1995) The effective elastic thickness (Te) of continental lithosphere: what does it really mean? J. Geophys. Res., 100, 3905-3927. doi:10.1029/94JB02770

Calais, E., D’Oreye, N., Albaric, J., Deschamps, A., Delvaux, D., Déverchère, J., Ebinger, C., et al. (2008). Strain accommodation by slow slip and dyking in a youthful continental rift, East Africa. Nature, 456, 783-788. doi:10.1038/nature07478

Cloetingh, S., Burov, E., Matenco, L., Beekman, F., Roure, F. \& Ziegler, P.A. (2013) The Moho in extensional tectonic settings: Insights from thermo-mechanical models. Tectonophysics, 609, 558-604, Elsevier B.V. doi:10.1016/j.tecto.2013.06.010

Corti, G., Iandelli, I. \& Cerca, M. (2013) Experimental modeling of rifting at craton margins. Geosphere, 9, 138-154. doi:10.1130/GES00863.1

Corti, G., Wijk, J. van, Cloetingh, S. \&Morley, C.K. (2007) Tectonic inheritance and continental rift architecture: Numerical and analogue models of the East African Rift system. Tectonics, 26, 1-13. doi:10.1029/2006TC002086

Currie, C., Van Wijk, J.(2016). How craton margins are preserved: Insights from geodynamic models, J. Geodynamics, 100, 144-158. doi:10.1016/j.jog.2016.03.015

Déverchère, J., Petit, C., Gileva, N., Radziminovitch, N., Melnikova, V. \& San'Kov, V. (2001) Depth distribution of earthquakes in the Baikal rift system and its implications for the rheology of the lithosphere. Geophys. J. Int., 146, 714-730. doi:10.1046/j.0956-540X.2001.1484.484.x 
Eberhart-Phillips, D. \& Fry, B. (2018). Joint local earthquake and teleseismic inversion for 3-D velocity and $\mathrm{Q}$ in New Zealand. Phys. Earth Planet. Inter., 283, 48-66, Elsevier. doi:10.1016/j.pepi.2018.08.005

Ebinger, C. J., Keir, D., Bastow, I. D., Whaler, K., Hammond, J. O., Ayele, A., et al. (2017). Crustal structure of active deformation zones in Africa: Implications for global crustal processes. Tectonics, 36, 3298-3332. https://doi.org/10.1002/2017TC004526

Ebinger, C., Djomani, Y.P., Mbede, E., Foster, A. \& Dawson, J.B. (1997) Rifting Archaean lithosphere: The Eyasi-Manyara-Natron rifts, East Africa. J. Geol. Soc. London., 154, 947-960. doi:10.1144/gsjgs.154.6.0947

Evans, J. \& Achauer, U., (1993). Teleseismic velocity tomography using the ACH method: theory and application to continental scale, Seismic tomography: Theory and Practice, pp. 319-360, Chapman and Hall.

Fishwick, S. (2010) Surface wave tomography: Imaging of the lithosphere-asthenosphere boundary beneath central and southern Africa? Lithos, 120, 63-73, Elsevier B.V. doi:10.1016/j.lithos.2010.05.011

Foley, S.F. (2008) Rejuvenation and erosion of the cratonic lithosphere. Nat. Geosci., 1, 503-510. doi:10.1038/ngeo261

Foster, A. N., Ebinger, C. J., Mbede, E., and Rex, D. (1997), Tectonic development of the northern Tanzanian sector of the East Afrícan Rift System,J. Geol. Soc. London, 154,689-700.

Fritz, H., Abdelsalam, M., Ali, K.A., Bingen, B., Collins, A.S., Fowler, A.R., Ghebreab, W., et al. (2013) Orogen styles in the East African Orogen: A review of the Neoproterozoic to Cambrian tectonic evolution. J. African Earth Sci., 86, 65-106, Elsevier Ltd. doi:10.1016/j.jafrearsci.2013.06.004 
Gama, R. (2018) Structure et propagation d'un rift magmatique en bordure de craton: Approche intégrée de la Divergence Nord-Tanzanienne par analyse des populations de failles et du réseau de drainage, Université de Bretagne Occidentale.

Gao, S. S., Liu, K. H., Davis, P. M., Slack, P. D., Zorin, Y. A., Mordvinova, V. V., and Kozhevnikov, V. M. (2003). Evidence for small-scale mantle convection in the upper mantle beneath the Baikal rift zone, J. Geophys. Res., 108, 2194, doi:10.1029/2002JB002039, B4.

Gao, S., Davis, P.M., Liu, H., Slack, P.D., Rigor, A.W., Zorin, Y.A., Mordvinova, V. V., et al, (1997) SKS splitting beneath continental rift zones. J. Geophys. Res., 102(B10), 22,781-22,797, doi:10.1029/97JB01858.

Gautier, S., Latorre, D., Virieux, J., Deschamps, A., Skarpelos, C., Sotiriou, A., Serpetsidaki, A., et al. (2006). A new passive tomography of the Aigion area (Gulf of Corinth, Greece) from the 2002 data set. Pure Appl. Geophys., 163, 431-453. doi:10.1007/s00024-005-0033-7

Gueydan, F., Morency, C. \& Brun, J.P. (2008) Continental rifting as a function of lithosphere mantle strength. Tectonophysics, 460, 83-93, Elsevier B.V. doi:10.1016/j.tecto.2008.08.012

Hardebol, N.J., Pysklywec, R.N. \& Stephenson, R. (2012) Small-scale convection at a continental back-arc to craton transition: Application to the southern Canadian Cordillera. J. Geophys. Res. Solid Earth, 117, 1-18. doi:10.1029/2011JB008431

Huang, H.-H., F.-C. Lin, B. Schmandt, J. Farrell, R. B. Smith, and V. C. Tsai (2015). The Yellowstone magmatic system from the mantle plume to the upper crust, Science, 348, doi:10.1126/science.aaa5648

Huang, H.H., Wu, Y.M., Song, X., Chang, C.H., Kuo-Chen, H. \& Lee, S.J. (2014). Investigating the lithospheric velocity structures beneath the Taiwan region by nonlinear joint inversion of focal and teleseismic P wave data: Slab continuity and deflection. Geophys. Res. Lett., 41, 63506357. doi:10.1002/2014GL061115 
Huerta, A.D., Nyblade, A.A. \& Reusch, A.M. (2009). Mantle transition zone structure beneath Kenya and Tanzania: More evidence for a deep-seated thermal upwelling in the mantle. Geophys. J. Int., 177, 1249-1255. doi:10.1111/j.1365-246X.2009.04092.x

Hui, H., Peslier, A. H., Rudnick, R. L., Simonetti, A., and Neal, C. R. (2015). Plume-cratonic lithosphere interaction recorded by water and other trace elements in peridotite xenoliths from the Labait volcano, Tanzania, Geochem. Geophys. Geosyst., 16, 1687- 1710, doi: $\underline{10.1002 / 2015 \mathrm{GC} 005779}$.

Huismans, R. \& Beaumont, C. (2011) Depth-dependent extension, two-stage breakup and cratonic underplating at rifted margins. Nature, 473, 74-78, Nature Publishing Group. doi:10.1038/nature09988

Humphreys, E.D. \& Clayton, R.W. (1990). Tomographic image of the southern California mantle. J. Geophys. Res., 95. doi:10.1029/jb095ib12p19725

Isola, Ilaria \& Mazzarini, Francesco \& Bonini, Marco \& Corti, Giacomo. (2014). Spatial variability of volcanic features in early-stage rift settings: The case of the Tanzania Divergence, East African rift system. Terra Nova. 26. n/a-n/a. 10.1111/ter.12121.

Kennett, B.L.N. \& Engdahl, E.R. (1991). Travel times for global earthquake location and phase association. Geophys. J. Int., 105, 429-465. doi:10.17611/DP/9991809

Key, R.M., Charsley, T.J., Hackman, B.D., Wilkinson, A.F. \& Rundle, C.C. (1989) Superimposed upper proterozoic collision-controlled orogenies in the Mozambique Orogenic Belt of Kenya. Precambrian Res., 44, 197-225. doi:10.1016/0301-9268(89)90045-4

Kissling, E., Ellsworth, W.L., Eberhart-Phillips, D. \& Kradolfer, U. (1994) Initial reference models in local earthquake tomography. J. Geophys. Res., 99. doi:10.1029/93jb03138

Koptev, A., Burov, E., Calais, E., Leroy, S., Gerya, T., Guillou-Frottier, L. \& Cloetingh, S. (2016). Contrasted continental rifting via plume-craton interaction: Applications to Central East African Rift. Geosci. Front., 7, 221-236, Elsevier Ltd. doi:10.1016/j.gsf.2015.11.002 
Koptev, A., Burov, E., Gerya, T., Pourhiet, L. Le, Leroy, S., Calais, E. \& Jolivet, L. (2018) Tectonophysics Plume-induced continental rifting and break-up in ultra-slow extension context: Insights from 3D numerical modeling. Tectonophysics, 746, 121-137, Elsevier B.V. doi:10.1016/j.tecto.2017.03.025

Koptev, A., Calais, E., Burov, E. et al. (2015). Dual continental rift systems generated by plumelithosphere interaction. Nature Geosci 8, 388-392, doi:10.1038/ngeo2401*

Kuo-Chen, H., F. T. Wu, and S. W. Roecker (2012). Three-Dimensional P Velocity Structures of the Lithosphere Beneath Taiwan from the Analysis of TAIGER and Related Seismic Data sets, J. Geophys. Res., 117, B06306, doi:10.1029/2011JB009108.

Le Gall, B. Le, Nonnotte, P., Rolet, J., Benoit, M., Guillou, H., Mousseau-Nonnotte, M., Albaric, J., et al. (2008). Rift propagation at craton margin. Distribution of faulting and yolcanism in the North Tanzanian Divergence (East Africa) during Neogene times. Tectonophysics, 448, 1-19. doi:10.1016/j.tecto.2007.11.005

Lee, H., Muirhead, J.D., Fischer, T.P., Ebinger, C.J., Kattenhorn, S.A., Sharp, Z.D. \& Kianji, G. (2016) Massive and prolonged deep carbon emissions associated with continental rifting. Nat. Geosci., 9, 145-149. doi:10.1038/ngeo2622

Lei, J. \& D. Zhao (2007). Teleseismia P-wave tomography and the upper mantle structure of the central Tien Shan orogenic belt. Phys, Earth Planet. Inter., 162, 165-185.

Lei, J., Zhao, D., Su, Y. (2009). Insight into the origin of the Tengchong intraplate volcano and seismotectonics in southwest China from local and teleseismic data, J. Geophys. Res., 114, p. B05302, 10.1029/2008JB005881

Liu, D \& Chen, L. (2019) Edge-driven convection and thinning of craton lithosphere: Twodimensional thermal-mechanical modeling. Sci. China Earth Sci., 62, 2106-2120. doi: $10.1007 / \mathrm{s} 11430-019-9371-0$ 
Maggi, A., Jackson, J.A., McKenzie, D. \& Priestley, K. (2000) Earthquake focal depths, effective elastic thickness, and the strength of the continental lithosphere. Geology, 28, 495-498. doi:10.1130/0091-7613(2000)28<495:efdeet $>2.0 . c o ; 2$

Mana, S., Furman, T., Carr, M.J., Mollel, G.F., Mortlock, R.A., Feigenson, M.D., Turrin, B.D., et al. (2012) Geochronology and geochemistry of the Essimingor volcano: Melting of metasomatized lithospheric mantle beneath the North Tanzanian Divergence zone (East African Rift). Lithos, 155, 310-325, Elsevier B.V. doi:10.1016/j.lithos.2012.09.009

Mana, S., Furman, T., Turrin, B.D., Feigenson, M.D. \& Swisher, C.C. (2015) Magmatic activity across the East African North Tanzanian Divergence Zone. J. Geol. Soc. London., 172, 368-389. doi:10.1144/jgs2014-072

Martin, M., Ritter, J.R.R. and CALIXTO working group (2005). High-resolution teleseismic bodywave tomography beneath SE Romania - I. Implications for three-dimensional versus onedimensional crustal correction strategies with a new crustal velocity model. Geophys. J. Int., 162: 448-460. doi:10.1111/j.1365-246X.2005.02661.x

Mattsson, H.B., Nandedkar, R.H. \& Ulmer, P. (2013) Petrogenesis of the melilititic and nephelinitic rock suites in the Lake Natron-Engaruka monogenetic volcanic field, northern Tanzania. Lithos, 179, 175-192, Elsevier B.V. doi:10.1016/j.lithos.2013.07.012

Muirhead, J.D., Fischer, T.P., Oliva, S,J., Laizer, A., Wijk, J. van, Currie, C.A., Lee, H., et al. (2020) Displaced cratonic mantle concentrates deep carbon during continental rifting. Nature, 582, 67-72, Springer US. doi:10.1038/s41586-020-2328-3

Muirhead, J.D., Kattenhorn, S.A. \& Corvec, N. Le. (2015). Varying styles of magmatic strain accommodation across the East African Rift. Geochemistry, Geophys. Geosystems. doi:10.1002/2015GC005918.

Muirhead, J.D., Kattenhorn, S.A., Lee, H., Mana, S., Turrin, B.D., Fischer, T.P., Kianji, G., et al. (2016). Evolution of upper crustal faulting assisted by magmatic volatile release during early- 
stage continental rift development in the East African Rift. Geosphere, 12, 1670-1700. doi:10.1130/GES01375.1

Mulibo, G. D., and Nyblade, A. A. (2013). Mantle transition zone thinning beneath eastern Africa: Evidence for a whole-mantle superplume structure, Geophys. Res. Lett., 40, 3562- 3566, doi:10.1002/grl.50694.

Njinju, E. A., Atekwana, E. A., Stamps, D. S., Abdelsalam, M. G., Atekwana, E. A., Mickus, K. L., et al. (2019). Lithospheric structure of the Malawi Rift: Implications for magma-poor rifting processes. Tectonics, 38, 3835- 3853. https://doi.org/10.1029/2019TC005549

Nonnotte, P. (2007) Etude volcano-tectonique de la zone de Divergence Nord Tanzanienne.

Nyamwandha, C.A., Powell, C.A. \& Langston, C.A. (2016). A joint local and teleseismic tomography study of the Mississippi Embayment and New Madrid Seismic Zone. J. Geophys. Res. Solid Earth, 121, 3570-3585. doi:10.1002/2015JB012761

Nyblade, A.A. \& Robinson, S.W. (1994) The African Superswell. Geophys. Res. Lett., 21, $765-$ 768.

O’Donnell, J.P., Adams, A., Nyblade, A.A., Mulibo, G.D. \& Tugume, F. (2013) The uppermost mantle shear wave velocity structure of eastern africa from rayleigh wave tomography: Constraints on rift evolution. Geophys. J. Int., 194, 961-978. doi:10.1093/gji/ggt135

Oliva, S. J., Ebinger, C. J., Wauthier, C., Muirhead, J. D., Roecker, S. W., Rivalta, E., \& Heimann, S. (2019). Insights Into Fault-Magma Interactions in an Early-Stage Continental Rift From Source Mechanisms and Correlated Volcano-Tectonic Earthquakes. Geophysical Research Letters, 46(4), 2065-2074. https://doi.org/10.1029/2018GL080866

Paige, C.C. \& Saunders, M.A. (1982) Algorithm 583: LSQR: Sparse Linear Equations and Least Squares Problems. ACM Trans. Math. Softw., 8, 195-209. doi:10.1145/355993.356000 
Pérez-Gussinyé, M., Metois, M., Fernández, M., Vergés, J., Fullea, J. \& Lowry, A.R. (2009) Effective elastic thickness of Africa and its relationship to other proxies for lithospheric structure and surface tectonics. Earth Planet. Sci. Lett., 287, 152-167, Elsevier B.V. doi:10.1016/j.eps1.2009.08.004

Petit, C. \& Ebinger, C. (2000) Flexure and mechanical behavior of cratonic lithosphere: Gravity models of the East African and Baikal rifts. J. Geophys. Res. Solid Earth, 105, 19151-19162. doi:10.1029/2000jb900101

Plasman, M., Hautot, S., Tarits, P., Gautier, S., Tiberi, C., Gall, B. Le, Mtelela, K., et al. (2019) Lithospheric structure of a transitional magmatic to amagmatic continental rift system-insights from magnetotelluric and local tomography studies in the north Tanzanian divergence, East African rift. Geosci., 9, 1-30. doi:10.3390/geosciences9110462

Plasman, M., Tiberi, C., Ebinger, C., Gautier, S., Albaric, J., Peyrat, S., Déverchére, J., et al. (2017) Lithospheric low-velocity zones associated with a magmatic segment of the Tanzanian Rift, East Africa. Geophys. J. Int., 210, 465-481. doi:10.1093/gji/ggx177

Podvin, P. \& Lecomte, I. (1991) Finite difference computation of traveltimes in very contrasted velocity models: a massively parallel approach and its associated tools. Geophys. J. Int., 105, 271-284. doi:10.1111/j.1365-246X.1991.tb03461.x

Poupinet, G., Thouvenot, F., Zolotov, E.E., Matte, P., Egorkin, A.V. \& Rackitov, V.A. (1997) Teleseismic tomography across the middle Urals: lithospheric trace of an ancient continental collision. Tectonophysics, 276, 19-33.

Priolo, E., Lovisa, L., Zollo, A., Böhm, G., D’Auria, L., Gautier, S., Gentile, F., et al. (2012) The Campi Flegrei blind test: Evaluating the imaging capability of local earthquake tomography in a volcanic area. Int. J. Geophys., 2012. doi:10.1155/2012/505286 
Rawlinson, N., and Urvoy, M. (2006), Simultaneous inversion of active and passive source datasets for 3-D seismic structure with application to Tasmania, Geophys. Res. Lett., 33, L24313, doi:10.1029/2006GL028105.

Rawlinson, N., Salmon, M. \& Kennett, B.L.N. (2014) Transportable seismic array tomography in southeast Australia: Illuminating the transition from Proterozoic to Phanerozoic lithosphere. Lithos, 189, 65-76, Elsevier B.V. doi:10.1016/j.lithos.2013.06.001

Ritsema, J., Nyblade, A.A., Owens, T.J., Langston, C.A. \& VanDecar, J.C. (1998) Upper mantle seismic velocity structure beneath Tanzania, east Africa: Implications for the stability of cratonic lithosphere. J. Geophys. Res. Solid Earth, 103, 21201-21213. doi:10.1029/98jb01274

Roecker, S. W., Sabitova, T. M., Vinnik, L. P., Burmakov, Y. A., Golvanov, M. I., Mamatkanova, R., and Munirova, L. (1993). Three-dimensional elastic wave velocity structure of the western and central Tien Shan, J. Geophys. Res., 98( B9), 15779- 15795, doi:10.1029/93JB01560.

Roecker, S., Ebinger, C., Tiberi, C., Mulibo, G., Mtelela, K., Kianji, G., Muzuka, A., et al. (2017) Subsurface images of the Eastern Rift, Africa, from the joint inversion of body waves, surface waves and gravity: investigating the role of fluids in early-stage continental rifting, Geophys. $J$. Int, 210(2), 931-950. doi:10.1093/gji/ggx220

Rudnick, R.L., McDonough, W.F. \& Chappell, B.W. (1993) Carbonatite metasomatism in the northern Tanzanian mantle: petrographic and geochemical characteristics. Earth Planet. Sci. Lett., 114, 463-475. doi:10.1016/0012-821X(93)90076-L

Ryberg, T. \& Haberland, C. (2019) Bayesian simultaneous inversion for local earthquake hypocentres and 1-D velocity structure using minimum prior knowledge. Geophys. J. Int., 218, 840-854, Oxford University Press. doi:10.1093/gji/ggz177

Sandoval, S., Kissling, E., Ansorge, J. \& SVEKALAPKO working group (2003) High-resolution body wave tomography beneath the SVEKALAPKO array: I. A priori three-dimensional crustal 
model and associated traveltime effects on teleseismic wave fronts. Geophys. J. Int., 153, 75-87. doi:10.1046/j.1365-246X.2003.01888.x

Santimano, T. \& Pysklywec, R. (2020) The influence of lithospheric mantle scars and rheology on intraplate deformation and orogenesis: Insights from tectonic analogue models. Tectonics, 1-19. doi:10.1029/2019tc005841

Scholz, C.H., 2002 The Mechanics of Earthquakes and Faulting, 2nd edition. Cambridge University Press, UK, p. 496.

Selway, K. (2015) Negligible effect of hydrogen content on plate strength in East Africa. Nat. Geosci., 8, 543-546. doi:10.1038/ngeo2453

Selway, K., Yi, J. \& Karato, S.I. (2014). Water content of the Tanzanian lithosphere from magnetotelluric data: Implications for cratonic growth and stability. Earth Planet. Sci. Lett., 388, 175-186, doi:10.1016/j.epsl.2013.11.024

Shackleton, R.M. (1986) Precambrian collision tectonics in Africa Collis. tectonics, 329-349.

Siler, D. L., \& Karson, J. A. (2017). Along-axis structure and crustal construction processes of spreading segments in Iceland: Implications for magmatic rifts. Tectonics, 36, 2068- 2084. https://doi.org/10.1002/2017TC004629

Sippel, J., Meeßen, C., Cacace, M., Mechie, J., Fishwick, S., Heine, C., Scheck-Wenderoth, M., et al. (2017) The Kenya rift revisited: Insights into lithospheric strength through data-driven 3-D gravity and thermal modelling. Solid Earth, 8, 45-81. doi:10.5194/se-8-45-2017

Soltanmohammadi, A., Grégoire, M., Rabinowicz, M., Gerbault, M., Ceuleneer, G., Rahgoshay, M., Bystricky, M., et al. (2018) Transport of volatile-rich melt from the mantle transition zone via compaction pockets: Implications for mantle metasomatism and the origin of Alkaline Lavas in the Turkish-Iranian plateau. J. Petrol., 59, 2273-2310. doi:10.1093/petrology/egy097 
Steck, L.K. \& Prothero, W.A. (1991) A 3-D raytracer for teleseismic body-wave arrival times. Bull. Geol. Soc. Am., 81, 1332-1339.

Tepp, G., Ebinger, C.J., Zal, H., Gallacher, R., Accardo, N., Shillington, D.J., Gaherty, J., et al. (2018). Seismic Anisotropy of the Upper Mantle Below the Western Rift, East Africa. J. Geophys. Res. Solid Earth, 123, 5644-5660. doi:10.1029/2017JB015409

Tesha, A.L., Nyblade, A.A., Keller, G.R. \& Doser, D.I. (1997) Rift localization in suture-thickened crust: Evidence from Bouguer gravity anomalies in northeastern Tanzania, East Africa, Tectonophysics, 278, 315-328. doi:10.1016/S0040-1951(97)00110-8

Thurber, C.H. (1983). Earthquake Locations and Three-Dimensional Crustal Strueture in the Coyote Lake Area, Central California. J., 88, 8226-8236. Retrieved from http://dx.doi.org/10.1029/JB088iB10p08226; doi:10.

Thurber, C.H. (1992) Hypocenter-velocity structure coupling in local earthquake tomography. Phys. Earth Planet. Inter., 75, 55-62. doi:10.1016/0031-9201(92)90117-E

Thybo H, Nielsen CA. Magma-compensated crustal thinning in continental rift zones. Nature. 2009; 457(7231):873-876. doi:10.1038/nature07688

Thybo, H., \& Artemieva, I. M. (2013). Moho and magmatic underplating in continental lithosphere. Tectonophysics, 609, 605-619. doi.org/10.1016/j.tecto.2013.05.032

Tiberi, C., Diament, M., Déverchère, J., Petit-Mariani, C., Mikhailov, V., Tikhotsky, S. \& Achauer, U. (2003). Deep structure of the Baikal rift zone revealed by joint inversion of gravity and seismology. J. Geophys. Res., 108. doi:10.1029/2002JB001880

Tiberi, C., Gautier, S., Ebinger, C., Roecker, S., Plasman, M., Albaric, J., Peyrat, S., et al. (2019). Lithospheric modification by extension and magmatism at the craton-orogenic boundary : North Tanzania Divergence, East Africa, Geophys. J. Int., 216(3), 1693-1710. doi:10.1093/gji/ggy521 
Tiberi, C., Lyon-Caen, H., Hatzfeld, D., Achauer, U., Karagianni, E., Kiratzi, A., Louvari, E., et al. (2000) Crustal and upper mantle structure beneath the Corinth rift (Greece) from a teleseismic tomography study. J. Geophys. Res. Solid Earth, 105, 28159-28171. doi:10.1029/2000jb900216

Van Wijk, J.W. , Baldridge, W.S., Hunen, J. van, Goes, S., Aster, R., Coblentz, D.D., Grand, S.P., et al. (2010) Small-scale convection at the edge of the Colorado Plateau: Implications for topography, magmatism, and evolution of Proterozoic lithosphere. Geology, 38, 611-614. doi:10.1130/G31031.1

Vauchez, A., Tommasi, A. \& Barruol, G. (1998) Rheological heterogeneity, mechanical anisotropy and deformation of the continental lithosphere. Tectonophysics, 296, 61-86. doi:10.1016/S00401951(98)00137-1

Vauchez, A., Tommasi, A., Barruol, G. \& Maumus, J. (2000) Upper Mantle Deformation and Seismic Anisotropy in Continental Rifts. Phys. Chem. Earth, 25, 111-117. doi:10.1046/j.1365246X.2002.01690.x

Waldhauser, F., Lippitsch, R., Kissling, E. \& Ansorge, J. (2002). High-resolution teleseismic tomography of upper-mantle structure using an a priori three-dimensional crustal model. Geophys. J. Int., 150, 403-414. doi:10.1046/j.1365-246X.2002.01690.x

Walker, K.T., Nyblade, A.A., Klemperer, S.L., Bokelmann, G.H.R. \& Owens, T.J. (2004) On the relationship between extension and anisotropy: Constraints from shear wave splitting across the East African Plateau. J. Geophys. Res. Solid Earth, 109. doi:10.1029/2003JB002866

Wallner, H. \& Schmeling, H. (2011). Sensitivity analysis of rift induced delamination with application to Rwenzori Mountains, Geophys. J. Int., 187(3), 1135-1145, https://doi.org/10.1111/j.1365-246X.2011.05237.x

Wang, H., and Currie, C. A. (2015). Magmatic expressions of continental lithosphere removal, J. Geophys. Res. Solid Earth, 120, 7239- 7260, doi:10.1002/2015JB012112. 
Wang, H., Hunen, J. van \& Pearson, D.G. (2015) The thinning of subcontinental lithosphere: the roles of plume impact and metasomatic weakening. Geochemistry Geophys. Geosystems, 16, 1156-1171. doi:10.1002/2015GC005784

Wang, H., Hunen, J. van, Pearson, D.G. \& Allen, M.B. (2014) Craton stability and longevity: The roles of composition-dependent rheology and buoyancy. Earth Planet. Sci. Lett., 391, 224-233, Elsevier B.V. doi:10.1016/j.epsl.2014.01.038

Weeraratne, D.S., Forsyth, D.W., Fischer, K.M. \& Nyblade, A.A. (2003). Evidence for an upper mantle plume beneath the Tanzanian craton from Rayleigh wave tomography. J. Geophys. Res. Solid Earth, 108. doi:10.1029/2002jb002273

Weinstein, A., Oliva, S.J., Ebinger, C.J., Roecker, S., Tiberi, C., Aman, M., Lambert, C., et al. (2017). Fault-magma interactions during early continental rifting: Seismicity of the MagadiNatron-Manyara basins, Africa. Geochemistry, Geophys. Geosystems, 18, 3662-3686. doi:10.1002/2017GC007027

Wilkinson, P., Mitchell, J.G., Cattermole, P.J. \& Downie, C. (1986) Volcanic chronology of the Meru-Kilimanjaro region, northern Tanzania. J. Geol. Soc. London., 143, 601-605. doi:10.1144/gsjgs.143.4.0601

Zeyen, H. \& Achauer, U. (2002). Joint inversion of teleseismic delay times and gravity anomaly data: A new approach in Upper mantle heterogeneities from active and passive seismology ed. Dordrecht, Springer., pp. 155-168.

Zhang, Q., Sandvol, E. \& Liu, M. (2009). Lithospheric velocity structure of the New Madrid Seismic Zone: A joint teleseismic and local P tomographic study. Geophys. Res. Lett., 36, 1-6. doi:10.1029/2009GL037687

Zháo, D., Hasegawa, A. \& Horiuchi, S. (1992). Tomographic imaging of P and S wave velocity structure beneath northeastern Japan. J. Geophys. Res., 97, 19909. doi:10.1029/92JB00603 
Zhao, D., Hasegawa, A. \& Kanamori, H. (1994). Deep structure of Japan subduction zone as derived from local, regional, and teleseismic events. J. Geophys. Res. Solid Earth, 99, 2231322329. doi:10.1029/94JB01149

Zhao, D., Kanamori, H. \& Humphreys, E. (1996). Simultaneous inversion of local and teleseismic data for the crust and mantle structure of southern California. Phys. Earth Planet. Inter., 93, 191214. doi:10.1016/0031-9201(95)03076-X

Ziegler, P.A. \& Cloetingh, S. (2004) Dynamic processes controlling evolution of rifted basins, Earth-Science Rev., 64, 1-50. doi:10.1016/S0012-8252(03)00041-2 